\title{
O Documento "Proposta para Base Nacional Comum da Formação de Professores da Educação Básica” (BNCFP): Dez Razões para Temer e Contestar a BNCFP ${ }^{1}$
}

\section{The Document "Proposal for Common National Base to Teacher Education" (BNCFP): Ten Reasons to Fear and Confute the BNCFP}

\author{
Larissa Zancan Rodrigues ${ }^{\circledR}$ Brasil \\ Beatriz Pereira ${ }^{\circ}$ Brasil \\ Adriana Mohr ${ }^{\circledR}$ Brasil
}

Apresentamos e analisamos o documento "Proposta para Base Nacional Comum da Formação de Professores da Educação Básica" (BNCFP), que foi encaminhado pelo Ministério da Educação (MEC) ao Conselho Nacional de Educação (CNE)em dezembro de 2018. Inicialmente descrevemos o contexto de formulação, as exigências normativas, a autoria, a estrutura e o conteúdo da BNCFP. Em seguida, identificamos dez pontos de análise que nos parecem cruciais para o campo da Educação em Ciências, uma vez que impactam fortemente os currículos e os princípios da formação e da atuação dos professores. Ao final do texto, trazemos um pós-escrito, de caráter informativo e complementar para analise da BNCFP, a fim de relatar os acontecimentos ocorridos de setembro a novembro de 2019 pertinentes a este documento no CNE.

Palavras-chave: currículo; formação de professores; ensino superior; ensino de ciências.

We describe and analyze the document "Proposal for Common National Base to Teacher Education" (BNCFP), submitted to Brazilian National Council for Education (CNE) by the Minister of Education in December 2018. We describe the context of its elaboration, the regulatory requirements, its authors, the structure and the content of BNCFP. We identify ten points that are crucial to those who work the field of Science Education, as they impact strongly the curricula and the principles of teacher education and the performance of the teachers. We finished by offering an informative and complementary post-scriptum to our analysis of the BNCFP, in order to report on the events occurred

1 Este texto é versão derivada de palestra na mesa redonda "A educação em ciências na escola democrática: avanços e retrocessos das políticas de formação docente (BNCC, PIBID, Residência Pedagógica)”, havida no XII Encontro Nacional de Pesquisa em Educação em Ciências, na Universidade Federal do Rio Grande do Norte, Natal, em 25 de junho de 2019. O texto original foi finalizado em maio de 2019. Para a presente publicação acrescentamos um pós-escrito, que resume tramitações atinentes à BNCFP após julho de 2019. 
from September to November relative to the approval of this document by the CNE.

Keywords: curriculum; teacher training; higher education; science teaching.

\section{Introdução}

Uma base curricular comum, tal como organizada no País, pressupõe apostar em um registro estabelecido como tendo um selo oficial de verdade, um conjunto de conteúdos que adquire o poder de conhecimento essencial a ser ensinado e aprendido, metas uniformes e projetos identitários fixos, trajetórias de vida preconcebidas, esforços para tentar conter a tradução e impor uma leitura curricular como a única correta e obrigatória. Pressupõe apostar no consenso curricular como se ele fosse possível fora da disputa política contingente. Pressupõe ainda situar o debate e a deliberação política em uma etapa anterior ao texto promulgado, como se uma vez estabelecida a base, a política, com seus conflitos e antagonismos, cessasse. (Lopes, 2019).

As escolas se encontram em uma espécie de crise crônica diante das contradições que lhe são inerentes, já que são instituições que podem tanto contribuir para reprodução como para transformação social. Contudo, nas últimas décadas, esse quadro se tornou mais agudo e profundo diante do estabelecimento do neoliberalismo. No contexto de um mundo globalizado e profundamente modificado pelos avanços científicos e tecnológicos, largos processos de liberalização econômica com reforço do papel do setor privado na economia têm ocorrido, o que contribui para a inclusão da lógica de funcionamento desse setor naquilo que é de ordem pública e coletiva que, em tese, deveria ser garantido pelo Estado.

O surgimento do Estado precede ao desenvolvimento do capitalismo, mas esse foi formado diante do afastamento das barreiras naturais que geravam escassez nas comunidades mais antigas, assim como pelo estabelecimento da propriedade privada. Com o passar do tempo, o Estado foi constituindo mecanismos de poder, via instituições e seus instrumentos jurídicos, para, por exemplo, deter o monopólio da violência e da força para a manutenção de certas hegemonias. É nesse sentido que são realizadas aquilo que chamamos de políticas públicas que, para Di Giovanni (2009), vão além da ideia de intervenção do Estado em uma situação considerada problemática:

Mais do que isso, penso a política pública como uma forma contemporânea de exercício do poder nas sociedades democráticas, resultante de uma complexa interação entre o Estado e a sociedade, entendida aqui num sentido amplo, que inclui as relações sociais travadas também no campo da economia. Penso, também, que é exatamente nessa interação que se definem as situações sociais consideradas problemáticas, bem como as formas, os conteúdos, os meios, os sentidos e as modalidades de intervenção estatal. (p. 4-5).

No Brasil, o Plano Nacional da Educação (PNE) costuma ser elaborado no âmbito da Conferência Nacional de Educação (CONAE) e estabelece diretrizes, metas e estratégias que regem as políticas educacionais. $\mathrm{O}$ atual Plano, vigente para a década de 
2014-2024, estabelece vinte metas para educação em aspectos como universalização da alfabetização e ampliação da escolaridade e das oportunidades educacionais, redução das desigualdades e valorização da diversidade, valorização dos profissionais da educação e responsabilidade dos governos federal e estaduais com a formação no nível superior (Lei 13.005, 2014). Destacamos que esses aspectos fazem referência a algumas das ideias apresentadas no relatório final da última CONAE (2014), as quais foram incorporadas de maneira seletiva na versão final do documento, que tem fomentado ações que priorizam o desenvolvimento de políticas de centralização curricular:

Chamo política de centralização curricular toda política de homogeneização de currículos, não necessariamente nacional, que subsidie outras políticas (de material didático, de avaliação, de formação docente, etc.). Nessa categoria se enquadram a BNCC, a grossa maioria das propostas curriculares de estados e municípios e, em alguns sentidos, os Parâmetros Curriculares Nacionais (PCN). (Cássio, 2018, p. 251).

Especificamente neste artigo, analisamos a "Proposta para Base Nacional Comum da Formação de Professores da Educação Básica” (BNCFP), encaminhada pelo Ministério da Educação (MEC) ao Conselho Nacional de Educação (CNE) em 14 dezembro de 2018 (MEC, 2018a). Esse documento, entre outras mudanças, anuncia a intenção de alterar as diretrizes vigentes para a formação inicial e continuada de professores e sua importância no cenário das políticas educacionais demanda e recomenda muita atenção e análise não só de suas propostas e consequências, mas também dos fundamentos que o embasam e dão razão para sua existência. Acreditamos que o conhecimento e o debate da proposta são fundamentais aos pesquisadores e formadores e professores do campo da Educação em Ciências. Tal como a Base Nacional Comum Curricular (BNCC) e atrelada a ela, a BNCFP acena com mudanças de fundamentos, objetivos, conteúdo e estrutura da formação inicial e continuada de professores. Conhecer, apropriar-se, desvelar e debater o documento nos parecem etapas fundamentais para posicionamento e ação crítica.

Assim, o objetivo do presente artigo é apresentar e analisar o texto da BNCFP. Para isto, inicialmente caracterizamos alguns aspectos gerais do documento incluindo contexto de formulação, exigências normativas, autoria, estrutura e conteúdo. $\mathrm{Na}$ sequência, apresentamos dez pontos de análise que nos parecem cruciais para o campo da Educação em Ciências uma vez que impactam fortemente os currículos e os princípios da formação e da atuação dos professores.

\section{Contexto de Formulação}

Para compreender a BNCFP precisamos mencionar o panorama geral no qual ela se insere e destacar que ela foi concebida para ser uma das peças importantes do sistema de políticas educacionais atuais no Brasil. Isto significa situar o documento como integrante de um conjunto sistêmico e complexo de ações, políticas e justificativas que se retroalimentam.

Por exemplo, em 1995, o Sistema de Avaliação da Educação Básica (SAEB), 
criado em 1990, passou por reestruturação metodológica que possibilitou a comparação dos desempenhos dos estudantes ao longo dos anos. Lembremos também que em 2009 passou-se usar a prova do então chamado novo ENEM, para o ingresso no ensino superior e induzir, de forma indireta, mudanças curriculares no Ensino Médio. A partir desses acontecimentos e de outras mudanças, percebemos que não é de hoje que estão sendo feitas mudanças e reformas na educação brasileira com finalidade de gerar um progressivo alinhamento entre objetivos de aprendizagem a serem atingidos pelos estudantes, sistematizados em matrizes curriculares e a sua avaliação por meio de testes padronizados. Nos últimos três anos, os processos de articulação ensino-aprendizagemavaliação têm se aprofundado e se acelerado.

Esse alinhamento é expresso textualmente na versão final da BNCC, aprovada em dezembro de 2017:

Referência nacional para a formulação dos currículos dos sistemas e das redes escolares dos Estados, do Distrito Federal e dos Municípios e das propostas pedagógicas das instituições escolares, a BNCC integra a política nacional da Educação Básica e vai contribuir para o alinhamento de outras políticas e ações, em âmbito federal, estadual e municipal, referentes à formação de professores, à avaliação, à elaboração de conteúdos educacionais e aos critérios para a oferta de infraestrutura adequada para o pleno desenvolvimento da educação. (CNE, 2017, p. 8, grifos nossos).

Mas, a vinculação estrutural das políticas já estava presente também, como imagem, na segunda versão, de 2016, da BNCC (Figura 1).

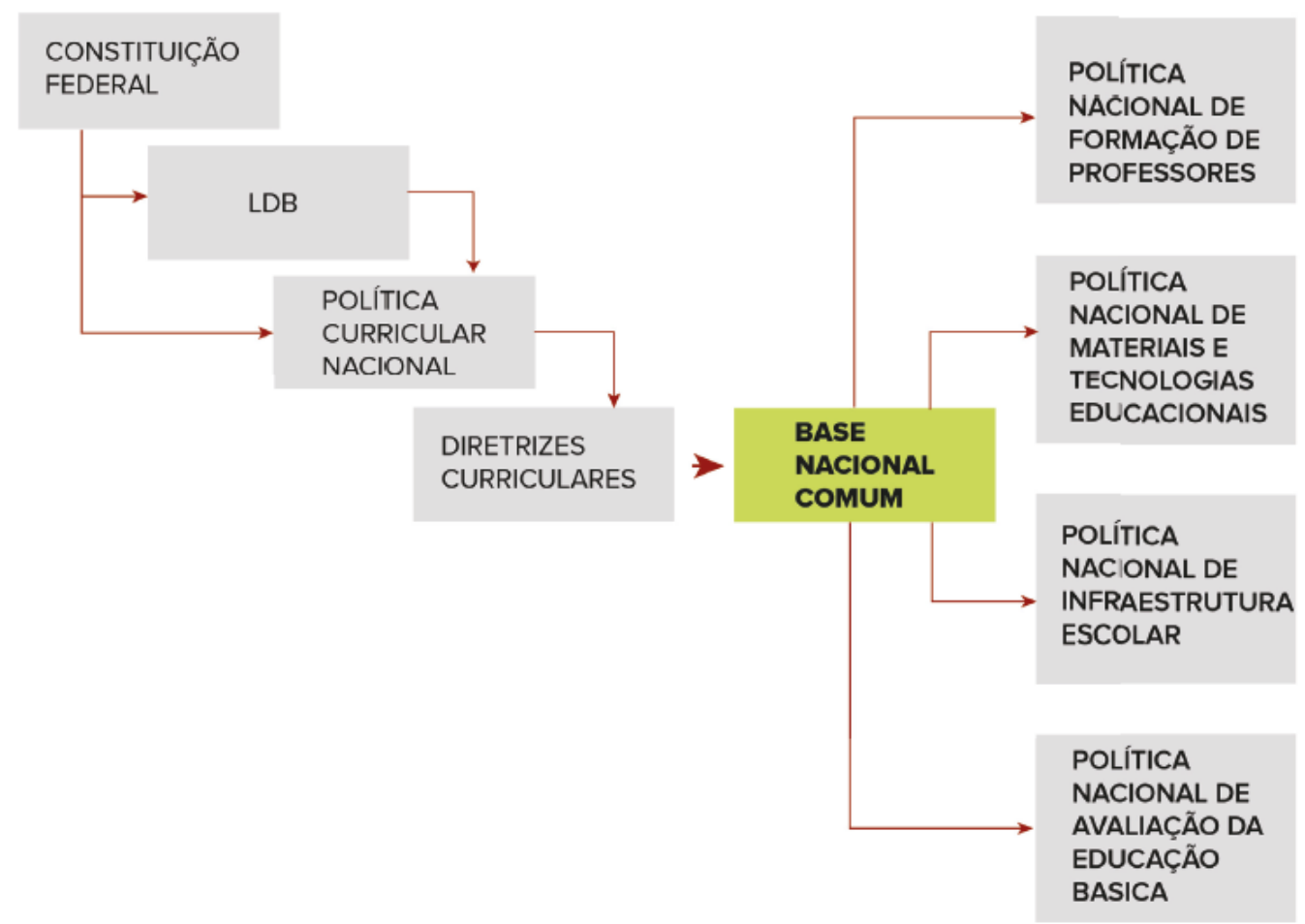

Figura 1. Elementos da política educacional brasileira contemporânea segundo a BNCC, $2^{\text {a }}$ versão (MEC, 2016, p. 26) 
Ou seja, vemos que os autores da BNCC localizam a origem desse documento em supostas exigências normativas (das quais trataremos na sequência do texto) e dele derivam políticas de formação de professores, de materiais e tecnologias educacionais, de infraestrutura escolar e de avaliação da educação básica. Por trás dessas e de outras reformas há ideias falsas, mas infelizmente muito alardeadas, de que a gestão pública é ineficaz, devido à falta de competitividade entre as instituições e indivíduos, que boa educação é aquela voltada para médias altas em exames e que entendem a aprendizagem como um conjunto de competências e habilidades, sistematizadas em matrizes de referência, que devem ser apreendidas pelos estudantes.

Tais ideias extravasam o campo do pensamento dos elaboradores de políticas públicas e estão fortemente presentes no imaginário da população: existe a percepção generalizada de que educação pública no Brasil vai mal, o que é reforçado, principalmente, quando manchetes de jornais e revistas trazem os baixos resultados obtidos pelos estudantes em avaliações em larga escala (PISA ${ }^{2}$, ENEM, SAEB) ou por faixas colocadas em frente às escolas que gabam desempenhos nos testes.

Essa política de alinhamento (objetivo-conteúdo-teste) gera um estreitamento curricular, pois secundariza dimensões mais amplas da formação humana e não considera de fato a influência do perfil socioeconômico dos indivíduos na aprendizagem. Tais iniciativas têm, ainda, um caráter de responsabilização individual forte, que não é coerente com a realidade do Brasil, em que a desigualdade social é histórica e muito profunda.

Por outro lado, é interessante pensar as razões de por que, dentre as vinte metas do PNE (2014-2024), aquelas ligadas a questões curriculares foram as que mais avançaram, mesmo que as comunidades escolar e acadêmica da área da Educação reconheçam que mudanças em currículos, dadas por imposição vertical e desarticuladas de outras iniciativas, historicamente fracassam. Destacamos, ainda, que é recorrente, no texto da BNCFP, o uso de palavras como "resultados", "eficiência", "desempenho", "objetivos" e a própria tríade "ensino-aprendizagem-avaliação", o que nos faz aproximar a proposta da BNCFP às teorias tradicionais de currículo (Silva, 2005), diante das quais o campo de pesquisa em Educação já avançou e apresenta outras perspectivas possíveis.

\section{Que Normas Legais Mencionam e Egiririam uma Base para a Formação de Professores?}

Na Figura 2 destacamos legislações nacionais e a expressão referente à base curricular, ou assemelhada, presente para a educação básica (EB) ou superior (ES) (formação de professores).

2 O Programa Internacional de Avaliação de Estudantes (Pisa), tradução de Programme for International Student Assessment, é um estudo comparativo internacional, realizado a cada três anos pela Organização para a Cooperação e Desenvolvimento Econômico (OCDE). 


\begin{tabular}{|c|c|c|c|c|}
\hline Legislação & Data & Expressão utilizada & EB & ES \\
\hline Constituição (1988) & 1988 & $\begin{array}{l}\text { "plano nacional de educação" } \\
\text { (art. } 60,211,213 \text { e } 214)\end{array}$ & $\mathrm{x}$ & \\
\hline $\begin{array}{l}\text { Lei de Diretrizes e Bases da Educação } \\
\text { Nacional (LDBEN) (Lei 9.394, 1996) }\end{array}$ & $\begin{array}{l}1996 \\
2017\end{array}$ & $\begin{array}{l}\text { "base nacional comum" (art. 26) - } \\
\text { texto original de } 1996 . \\
\text { "base nacional do currículo" (art. } \\
\text { 38) - texto original de } 1996 \\
\text { "base nacional comum. } \\
\text { curricular" (art. 26, 35-A, 36,44 } \\
\text { e 62) - redação dada pela Lei n. } \\
\text { 13.415 de 2017. }\end{array}$ & $\mathrm{x}$ & \\
\hline $\begin{array}{l}\text { Diretrizes Curriculares Nacionais para } \\
\text { Formação de Professores (CNE, 2002) }\end{array}$ & 2002 & $\begin{array}{l}\text { "matriz curricular" (art. 10, } 11 \text { e } \\
\text { 12) }\end{array}$ & & $\mathrm{x}$ \\
\hline $\begin{array}{l}\text { Plano Nacional de Educação (Lei n. 13.005, } \\
\text { 2014) }\end{array}$ & 2014 & $\begin{array}{l}\text { "base nacional comum dos } \\
\text { currículos"(pág. 115) }\end{array}$ & $\mathrm{x}$ & \\
\hline $\begin{array}{l}\text { Diretrizes Curriculares Nacionais para a } \\
\text { formação inicial em nível superior (cursos } \\
\text { de licenciatura, cursos de formação } \\
\text { pedagógica para graduados e cursos de } \\
\text { segunda licenciatura) e para a formação } \\
\text { continuada (CNE, 2015) }\end{array}$ & 2015 & $\begin{array}{l}\text { "base comum nacional" (pág. 2, 5, } \\
6,9,11 \text { e } 15 \text { ) }\end{array}$ & & $\mathrm{x}$ \\
\hline $\begin{array}{l}\text { Política Nacional de Formação dos } \\
\text { Profissionais da Educação Básica (Decreto } \\
\text { n. 8.752, 2016) }\end{array}$ & 2016 & $\begin{array}{l}\text { "Base Nacional Comum } \\
\text { Curricular" (art. } 1 \text { e 12) }\end{array}$ & & $\mathrm{x}$ \\
\hline $\begin{array}{l}\text { Reforma do Ensino Médio (Lei n. 13.415, } \\
\text { 2017) }\end{array}$ & 2017 & $\begin{array}{l}\text { "Base Nacional Comum } \\
\text { curricular"(art.2,3,4,4,7,11 e 12) }\end{array}$ & $\mathrm{x}$ & \\
\hline
\end{tabular}

Figura 2. Legislações nacionais e termos ali constantes sobre documentos curriculares (para educação básica e para formação de professores)

Sobre o surgimento da BNCFP, seu documento afirma que ela foi criada para atender ao disposto na legislação educacional e às deliberações do CNE e à LDBEN. No entanto, vemos que a redação original da LDBEN (Lei n. 9.394, 1996), mencionava apenas que "Os currículos do ensino fundamental e médio devem ter uma base nacional comum" (art. 26, grifo nosso). A primeira menção a uma "base nacional comum dos currículos” para a educação básica ocorre apenas em 2014 no PNE (Lei 13.005, 2014, pág. 115). É somente em 2017, 21 anos após a promulgação da LDB, que esta é modificada pela Lei n. 13.415 e passa então a incluir a menção à "Base Nacional Comum Curricular" (grifo nosso). Com relação a uma base para a formação de professores, a primeira menção ocorre em 2015 e refere-se a uma "base comum nacional".

Além disto, temos que considerar que, se desde 2015 se menciona a necessidade de uma base para a formação de professores, não é desta proposta de base que estamos necessária e obrigatoriamente falando. 
Farias (2019) contribui com nossas reflexões:

Houve a dissolução do Fórum Nacional de Educação (FNE), que restringiu a participação da sociedade civil e concentrou na figura do ministro da pasta a responsabilidade de decidir quem entra e quem sai de sua composição, bem como as sucessivas reestruturações da Comissão Bicameral da Base Nacional Comum do CNE, responsável por acompanhar e contribuir com o MEC na elaboração de documento sobre direitos e objetivos de aprendizagem e desenvolvimento, visando o cumprimento de estratégias das Metas 2 e 3 do Plano Nacional de Educação (PNE). Não são poucos e nem inexpressivos os sinais da imposição contínua de políticas sem debate por parte do MEC no atual governo, ação fortemente denunciada pela Associação Nacional de Pós-Graduação e Pesquisa em Educação (Anped), Associação Nacional pela Formação dos Profissionais da Educação (Anfope), Associação Brasileira de Currículo (ABdC) e demais entidades da área. (p. 158).

Ou seja, percebemos, nesse caso, o movimento de justificação de um documento embasado por demandas legais artificialmente colocadas e que apaga as histórias curriculares construídas até o momento, o que torna a justificativa baseada em imperativos legais para a existência da base muito frágil. Além disto, pretende-se aprovar e implementar o documento de forma verticalizada, sem diálogo, participação e discussão com a comunidade educacional e acadêmica.

\section{Autoria}

São seis autores os autores do documento: Maria Alice Carraturi Pereira, Guiomar Namo de Mello, Bruna Henrique Caruso, Fernando Luiz Abrucio, Catarina Ianni Segatto, Lara Elen Ramos Simielli, sendo que a primeira consta como "Organizadora". Há também três colaboradores: Caroline Tavares da Silva, Francisco Aparecido Cordão, Bahij Amin Aur.

Em uma breve análise do currículo Lattes de cinco autores (de quatro não encontramos currículo naquela plataforma) percebe-se que eles têm formação acadêmica e experiência profissional que nos permite caracterizá-los como pessoas que são/estão ligadas a grupos de "reformadores empresariais"3 e não a "educadores profissionais" (Freitas, 2012).

3 O termo "Corporate reformers" (traduzido como "reformadores empresariais da educação" no Brasil) é o termo cunhado por Diane Ravitch no livro "Vida e morte do grande sistema escolar americano", publicado em 2011. Ao utilizá-lo, a autora se refere a uma coalizão entre políticos, mídia, empresários, empresas educacionais, institutos e fundações privadas e pesquisadores alinhados com a ideia de que o mercado e o modo de organizar a iniciativa privada é uma proposta mais adequada para a melhoria da educação americana, que contrastam com as propostas feitas pelos educadores profissionais, que apostam na transformação social, visando o desenvolvimento da solidariedade entre as pessoas, a valorização da auto-organização dos estudantes e do trabalho coletivo, bem como o respeito à diversidade cultural. 
Farias (2019) tem a mesma leitura, identifica o pertencimento dos autores e afirma:

A composição da equipe de autores responsáveis pela elaboração da "Proposta para Base Nacional Comum da Formação de Professores da Educação Básica" não nos permite pensar de outra maneira. Os seis profissionais envolvidos nesta tarefa Maria Alice Carraturi Pereira (Hélade Consultoria em Educação), Guiomar Namo de Mello (Fundação Victor Civita), Bruna Henrique Caruso (SEB/MEC), Fernando Luiz Abrucio (FGV), Catarina Ianni Segatto (Eaesp/CEAPG) e Lara Elena Ramos Simielli (Eaesp/FGV) (BRASIL, 2018) - registram trajetórias marcadas por atuação na área da administração, da educação à [sic] distância e no setor empresarial e educacional privado. (p. 161).

\section{Estrutura, Conteúdo, Relações e Papel da BNCFP Frente a Outras Políticas Educacionais}

Curiosamente o documento da BNCFP não é facilmente encontrado. $\mathrm{O}$ arquivo PDF está hospedado em uma página do MEC, não muito acessível pela procura direta em buscadores de internet e que tem entrada pelo site do CNE, opção 'divulgação's.

A BNCFP é um documento de 65 páginas elaborado pelo MEC em 2018 e enviada ao CNE para apreciação e aprovação deste órgão em 14 de dezembro de 2018.

Em 19 de fevereiro de 2019, sob novo governo, o MEC solicitou a interrupção da tramitação da base no CNE. Segundo o MEC, o órgão quer "ter ciência e participar do processo de formulação da Base. Só depois da análise do documento é que o MEC decidirá se fará ou não alterações".

Apesar da proposta de BNCFP ter sido, então, um documento "em suspenso" (ou seria melhor dizer "no limbo"?), por que ocupar-se ou preocupar-se com ela? Em primeiro lugar porque a própria existência da BNCC prevê e pressupõe, como condição de sua implementação, a existência de uma BNCFP:

A primeira tarefa de responsabilidade direta da União será a revisão da formação inicial e continuada dos professores para alinhá-las à BNCC. A ação nacional será crucial nessa iniciativa [...]. Diante das evidências sobre a relevância dos professores e demais membros da equipe escolar para o sucesso dos alunos, essa é uma ação fundamental para a implementação eficaz da BNCC. (CNE, 2017, p. 21, grifos nossos).

Além disto, a equipe do MEC que elaborou a proposta de BNCFP é bastante alinhada com muitos dos atuais conselheiros do Conselho Nacional de Educação. Em abril de 2018 foram nomeados 24 conselheiros: cinco foram reconduzidos e cinco foram substituídos antes do fim de seus mandatos ${ }^{6}$. Este fato nos faz supor certa continuidade

4 http://portal.mec.gov.br/index.php?option=com_docman\&view=download\&alias=105091-bnc-formacao-deprofessores-v0\&category_slug=dezembro-2018-pdf\&Itemid=30192

5 https://www1.folha.uol.com.br/educacao/2019/02/mec-interrompe-discussoes-em-conselho-nacional-sobreformacao-de-professores.shtml

6 https://g1.globo.com/educacao/noticia/apos-revogar-indicacoes-feitas-por-dilma-temer-nomeia-membros-doconselho-nacional-de-educacao-com-seis-meses-de-antecedencia.ghtml 
nos órgãos legislativos educacionais, mesmo com a troca de comando do executivo no início do ano de 2019.

Pelo exposto, é fundamental conhecer as origens, conteúdo e propostas de BNCFP que fornecem elementos importantes para analisar e refletir sobre políticas educacionais brasileiras atuais, tais como as curriculares, de material didático, exames e avaliações em larga escala que nos impactam a todos como professores, pesquisadores ou formadores.

Como já mencionamos anteriormente, segundo seus autores, esta BNCFP é condição "fundamental" para implantação efetiva e "eficaz" da BNCC:

A primeira tarefa de responsabilidade direta da União será a revisão da formação inicial e continuada dos professores para alinhá-las à BNCC. A ação nacional será crucial nessa iniciativa, [...]. Diante das evidências sobre a relevância dos professores e demais membros da equipe escolar para o sucesso dos alunos, essa é uma ação fundamental para a implementação eficaz da BNCC. (MEC, 2017, p. 21, grifos nosso).

A BNCFP (e a BNCC que a originou) integram um sistema de políticas públicas educacionais engendrado com interdependência, alinhamento e padronização talvez nunca antes visto e explicitamente declarados em seus textos:

Referência nacional para a formulação dos currículos dos sistemas e das redes escolares dos Estados, do Distrito Federal e dos Municípios e das propostas pedagógicas das instituições escolares, a BNCC integra a política nacional da Educação Básica e vai contribuir para o alinhamento de outras políticas e ações, em âmbito federal, estadual e municipal, referentes à formação de professores, à avaliação, à elaboração de conteúdos educacionais e aos critérios para a oferta de infraestrutura adequada para o pleno desenvolvimento da educação. (MEC, 2017, p. 8, grifos nossos).

Vemos na Figura 1, anteriormente apresentada, o alinhamento das políticas mencionado. Além disso, percebemos que o documento se coloca como consequência, mas também é elemento fundamental para a existência e aplicação da BNCC.

A Figura 3, evidencia como a aprovação da BNCFP trará consequências extensas e com vasta tendência homogeneizadora no campo da formação, tanto inicial quanto continuada.

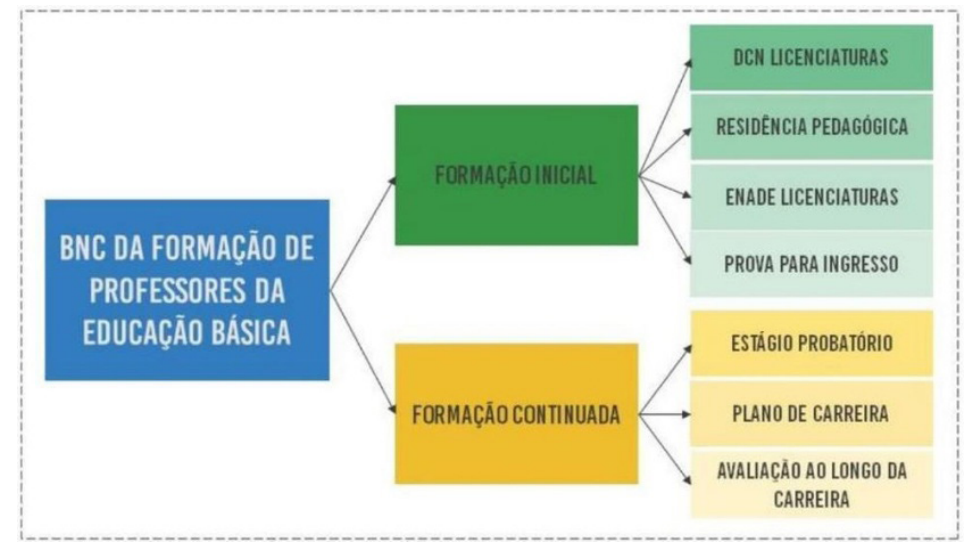

Figura 3. Relação da BNCFP com outras ações e políticas relacionadas à formação e exercício profissional da docência (MEC, 2018, p. 29) 
No que se refere às universidades, por exemplo, podemos indagar qual será a margem de autonomia para o estabelecimento e criação de currículos para as licenciaturas. Voltaremos a este assunto na razão 4.

Para finalizar este item apresentamos um resumo do conteúdo e estrutura da BNCFP.

O documento é composto por "Apresentação" e quatro capítulos, além de lista de "Bibliografia" com 45 referências citadas.

O primeiro capítulo - "Estado da arte da formação de professores", tem 15 páginas e meia página com três tópicos: "Histórico da formação de professores no Brasil" (7 páginas), "Referenciais docentes no Brasil" ( 2 páginas) e "Referenciais docentes internacionais" (6,5 páginas). Observamos aqui a desproporção entre a quantidade de páginas dedicadas a referenciais brasileiros e estrangeiros.

O capítulo 2, com 10,5 páginas, intitula-se "Visão sistêmica da formação" e apresenta um conjunto de seis ações e políticas interligadas à BNCFP: "Formação inicial" (4 páginas), "Residência Pedagógica" ( 2 páginas), "ENADE licenciaturas" (0,5 página), "Formação continuada" ( 3 páginas), "Estágio probatório" ( 0,5 página), "Plano de carreira e avaliação" (1,5 páginas).

O capítulo 3 tem 14 páginas e é o mais volumoso de todos. Ele apresenta a "Matriz de Competências Profissionais" que deverá ser ensinada e cobrada dos docentes. Este capítulo possui seis tópicos: "Competências profissionais" (2 páginas), "Conhecimento profissional” (2 páginas), "Prática profissional” (1 página.), "Engajamento profissional” (1 página), "Sinergia entre as funções de formação" (1 página), "Competências profissionais docentes" (7 páginas).

Por fim, o capítulo 4 "Limites e Indicações" (4,5 páginas) tece considerações sobre sete aspectos que deverão ser objeto de novos textos, legislações e providências: "Base de formação de gestores e técnicos", "Desenvolvimento dos níveis de competência por etapa de carreira", "Regulação das ações apresentadas na visão sistêmica", "Revisão da legislação vigente sobre as ações de formação docente", "Formação de professores da educação técnica profissional", "Formação de formadores e Instituto Nacional de acreditação" e "Formação de profissionais da educação básica".

\section{Retrocessos: Dez Razões Para Temer e Contestar a BNCFP}

Destacamos dez razões que nos fazem temer e contestar a proposta de BNCFP apresentada pelo MEC.

Embora os pontos que elencamos sejam profundamente ligados entre si, nos parece interessante a tentativa de individualizá-los. Esta é uma estratégia de estudo, mas também de enfrentamento e de reflexão sobre outras possibilidades. De acordo com Mainardes (2006), no contexto da prática, a política está sujeita à interpretação e recriação, produzindo efeitos e consequências que podem representar mudanças significativas na política original. Nesta perspectiva, nossa ação e aquilo que pensamos e defendemos têm implicações no processo de implementação das políticas. 


\section{1) Na BNCFP os Professores são os Grandes Responsáveis pelos Supostos Atual Fracasso e Futuro Sucesso da Educação Brasileira}

No segundo parágrafo do documento, ainda na seção de apresentação, as avaliações em larga escala internacionais, estaduais e municipais são apresentadas como instrumentos importantes para gerar dados sobre a educação no país. De acordo com o texto, elas foram aperfeiçoadas [...] "para monitorar a eficácia das políticas educacionais e analisar os fatores que incidem nos seus resultados" (MEC, 2018, p. 4). Nitidamente utilizadas como ferramenta de controle, o texto afirma que estas avaliações geram dados estatísticos que [...] "permitem fazer análises mais profundas a respeito das aprendizagens" (p. 5) e produzem evidências sobre o processo educativo no país (MEC, 2018). São apresentadas três destas supostas evidências:

a) a origem socioeconômica do aluno, sobre a qual a escola não tem controle, embora seja um fator que pese na determinação do desempenho escolar, pode ser compensada pela ação da escola,

b) os fatores que podem ser controlados pela escola ou pelo sistema educacional, dentre os quais o professor é, de longe, o que mais pesa na determinação do desempenho do aluno; $\mathrm{e}$

c) o papel desempenhado pelos professores bem preparados faz diferença significativa no desempenho dos alunos, independentemente do nível socioeconômico dos mesmos. (p. 5, grifos nossos).

O documento segue apresentando dados da Organização para a Cooperação e Desenvolvimento Econômico (OCDE) para afirmar que a qualidade dos professores é o fator mais importante para explicar o desempenho dos alunos. Chamamos a atenção para o fato de que para o documento este não é um dos fatores mais relevantes, ele é $o$ fator mais importante. Afirmações semelhantes estão presentes em diversos trechos da BNCFP e, desta forma, responsabilizam absurda e irresponsavelmente os docentes pelo desempenho dos alunos.

Esta lógica de culpar o docente é uma das consequências das reformas educacionais que foram iniciadas na maioria das sociedades ocidentais (Tardif, 2013). Não subestimamos a importância da escola enquanto instituição social que pode proporcionar mudanças na vida dos indivíduos, como sugere o documento. Porém, atribuir - às escolas, aos professores e aos próprios estudantes - a função de compensar problemas econômicos e sociais é uma responsabilização superdimensionada, ilusória e que desloca o foco dos diversos problemas da sociedade que impactam os processos de ensino-aprendizagem como ausência de garantia de saúde, moradia, alimentação, segurança, que também fazem parte das responsabilidades do Estado. Ao afirmar que o desempenho dos alunos independe do nível socioeconômico e que este pode ser compensado pela escola, o documento reafirma concepções meritocráticas de educação e desloca para um âmbito individual a responsabilidade em relação a desafios sociais 
mais amplos. Em diversos países, profissionais trabalham em condições extremamente difíceis, onde enfrentam pobreza, violência, falta de envolvimento das famílias, entre outros (Tardif, 2013). Culpar o docente causa desgaste moral nos professores:

[...] um sentimento de impotência ou de fracasso, acompanhado de uma falta de reconhecimento ou até mesmo de uma desvalorização profissional que conduz a um desânimo face a sua tarefa e uma impressão de inutilidade social. (Tardif, 2013, p. 567).

\section{2) BNCFP: Que Referenciais e Referências são essas?}

No documento da BNCFP, a seção dedicada à apresentação e discussão de referenciais docentes no Brasil ocupa duas páginas, enquanto que os referenciais docentes internacionais ocupam seis páginas e meia. Só este quantitativo seria indício preocupante. Mas há mais: o documento afirma na página 18 que "Há poucas iniciativas ou estudos no Brasil de referenciais de formação".

Há que se questionar fortemente se há mesmo, na literatura nacional, escassez de estudos e discussões sobre referenciais de formação docente ou se será o caso, como acreditamos, de que o imenso volume existente não diz ou sustenta o que os formuladores da BNCFP gostariam de ouvir e utilizar? Assim, uma suposta penúria bibliográfica nacional é justificativa para trazer referenciais internacionais, que são usados para responsabilizar o professor pelo desempenho dos alunos. Por exemplo, na página 19 somos informados de que:

A análise das experiências internacionais mostra que há um consenso em torno da importância do professor nos processos de aprendizagem, que está presente na literatura internacional e caracteriza as reformas educacionais realizadas nas últimas décadas em diversos países. Ainda que o contexto socioeconômico dos alunos tenha grandes implicações nos processos de aprendizagem, fatores intraescolares, principalmente a efetividade do professor, são considerados centrais para a melhoria dos resultados educacionais (Brooke, \& Soares, 2008; Rivkin, Hanushek, \& Kain, 2005). (MEC, 2018, grifo nosso).

Infelizmente nenhuma das duas referências está relacionada na bibliografia.

Com relação às 45 referências listadas no documento, uma análise rápida mostranos o seguinte panorama sumarizado na tabela 1 , de acordo com o tipo de documento.

Verificamos uma grande quantidade de menção a leis e normas, o que pode significar o desejo e/ou a necessidade de embasamento e justificativa do texto em peças normativas. Também nos chama a atenção que a segunda categoria de trabalhos mais citados seja aquela de textos com autoria de fundações e órgãos como OCDE, Todos pela Educação, etc. 
Tabela 1. Tipo de documento referenciado pela BNCFP

\begin{tabular}{lcc}
\hline Tipo de documento & N & \% do total \\
\hline Legislação/normas nacionais & 16 & 35,5 \\
Documentos de autoria de fundações e órgãos multilaterais & 7 & 15,5 \\
Periódicos estrangeiros & 6 & 13,3 \\
Periódicos brasileiros & 5 & 11,1 \\
Livros acadêmicos brasileiros & 3 & 6,6 \\
Livros de divulgação & 2 & 4,4 \\
Livros acadêmicos estrangeiros & 2 & 4,4 \\
Australian Council for Educational Research & 2 & 4,4 \\
Pesquisa em andamento & 1 & 2,2 \\
Sem dado & 1 & 2,2 \\
Total & 45 & \\
\hline
\end{tabular}

Destacamos que a citação de artigos e livros estrangeiros é semelhante às citações dos congêneres brasileiros, o que nos parece duplamente inadequado em um documento de política educacional no e do Brasil. Em primeiro lugar, porque cada realidade educacional é singular e não se presta a cópias. Em segundo lugar, há que considerar o volume e a qualidade da produção acadêmica brasileira disponível sobre os mais distintos tópicos da pesquisa educacional. Além disso, 18 referências, ou seja, $40 \%$ do total de referências utilizadas são estrangeiras, sendo que 13 (ou quase 30\%) delas não são traduzidas. Estes breves dados já dizem bastante sobre o documento e seu processo de formulação.

\section{3) A BNCFP Está Recheada de Chavões e Ideias de Senso Comum}

Ideias relacionadas à Teoria do Capital Intelectual são expressas nos primeiros parágrafos do texto da BNCFP:

Com transformações tão aceleradas do mundo contemporâneo, a educação precisa acompanhar o ritmo e formar os novos cidadãos para um mundo incerto e sempre novo. O desenvolvimento social e econômico está pautado no novo capital: o conhecimento. É ele que gera e agrega valor ao produto ou ao serviço, quando articulado a habilidades e valores. A revolução tecnológica e a sociedade do conhecimento trouxeram a educação para uma posição estratégica na agenda do desenvolvimento sustentável. (MEC, 2018, p. 4 , grifos nossos).

De acordo com Santos (2004), o surgimento da Teoria do Capital Humano tem relação, sobretudo, com o desenvolvimento de trabalhos de Theodore W. Schultz e Gary Becker, a partir dos anos de 1950, na Universidade de Chicago. Para Schultz, o trabalho humano, quando qualificado por meio da educação, é um dos mais importantes meios para a ampliação da produtividade econômica e, por consequência, das taxas de lucro do capital. Dessa forma, passou-se a defender que a educação é importante para o desenvolvimento econômico, assim como para o próprio desenvolvimento 
dos indivíduos. Isto deslocou, para o âmbito individual, a responsabilidade acerca de problemas relacionados a aspectos sociais mais amplos. Aplicada ao âmbito educacional, as ideias relacionadas à Teoria do Capital Humano geraram as concepções tecnicistas de educação, as quais, atualmente, são muito criticadas. Posteriormente, no contexto da reestruturação produtiva e do neoliberalismo, a Teoria do Capital Humano serviu de base para a construção da Teoria do Capital Intelectual, a qual reconhece o conhecimento como principal fator de produção na contemporaneidade. Nesse ínterim, o Estado, que antes era responsável pela formação do trabalhador, passou a ser desmontado e desmoralizado e o empresariado passou a dirigir e a executar os projetos educacionais sob a égide da necessidade de formação de um dito novo trabalhador. Este, em condições mais precarizadas de trabalho, deve ser capaz de atender as demandas colocadas a partir da difusão das novas tecnologias da informação e da comunicação.

O modelo de competências é originário do discurso empresarial, que se firma em meados da década de 80, tendo sido retomado por economistas e sociólogos, na França, ao longo dos anos 90, com vistas a compor um repertório para orientar a formação dos trabalhadores. Já naquele momento, eram apontados os riscos da imprecisão desse referencial quando comparado ao conceito de qualificação profissional, um dos conceitos chaves da Sociologia do Trabalho. As razões para o redirecionamento da formação para o trabalho, naquele contexto, estavam relacionadas às mudanças no terreno da gestão organizacional das empresas e também nas transformações tecnológicas em que processos informatizados passam a compor os meios de produção. (Silva, 2019, p. 125).

Em seguida, apresentam-se apenas dois estudos que fazem análises a respeito das possibilidades para a aprendizagem na educação básica e que destacam o papel do professor na melhoria do desempenho dos estudantes, a saber: "Teachers matters attracting, developing and retaining effective teachers", publicada pela OCDE, e "Como os sistemas escolares de melhor desempenho no mundo chegaram ao topo", da McKinsey \& Company. Cabe destacar que o último estudo está hospedado, no Brasil, na página do Instituto Net-Claro-Embratel que disponibiliza o estudo na íntegra a partir do site do grupo Todos pela Educação, uma organização fundada em 2006, que atende aos interesses dos chamados reformadores da educação. (Freitas, 2012; 2014; 2016).

Ao contrário do que seria de se esperar em um documento que embase e fundamente uma proposta de formação docente para o país, há muitas palavras e frases no documento que classificamos como chavões e/ou senso comum educacional:

Estudos realizados com resultados de avaliações indicam que a qualidade do sistema educacional está firmemente ancorada em uma visão sistêmica que valoriza os professores da educação básica, visto que são eles que formam cidadãos para os níveis subsequentes de educação e para todas as profissões e as vocações que estruturam um país desenvolvido nos aspectos humano, social, ambiental e econômico, com todas as correlações daí decorrentes. (MEC, 2018, p. 6)

Estas frases, palavras e ideias aparentemente belas e positivas não encontram efetividade ou possibilidade de efetivação tendo em vista os pressupostos e propostas 
que emergem do conjunto da BNCFP, os quais são muito incipientes do ponto de vista empírico e têm relação com objetivos de organizações com interesses econômicos de fundo. Para além da mais que discutível profundidade das ideias, o texto da BNCFP materializa um desserviço prestado à população não especialista no campo da pesquisa em Educação, pois não possibilita a identificação e compreensão das reais origens dos problemas da educação no Brasil.

Há, também, no texto analisado, termos com sentidos e significados diferentes que são usados como sinônimos, como ocorre com aprendizagem e desempenho. A noção de qualidade da educação é reduzida à qualidade de ensino, à assimilação de conteúdos, ao cumprimento de expectativa de aprendizagem. Todos estes elementos estão ligados à uma ideia linear de que professores bem preparados são professores que ensinam melhor e, por conseguinte, são professores cujos alunos aprendem mais (Farias, 2019).

\section{4) A BNCFP Exigirá Novas Diretrizes Curriculares para os Cursos de Licenciatura}

O texto afirma que: "Mais importante ainda, a BNCC deverá ser, daqui em diante, uma referência para a formação inicial e continuada dos professores. Abre-se assim uma janela de oportunidade para debater alguns dos entraves e dar qualidade à formação do professor brasileiro." (MEC, 2018, p. 7, grifo nosso).

Esta recomendação foi antecipadamente apropriada pelo Conselho de Secretários Estaduais de Educação (CONSED), que opera especialmente no campo da formação continuada. Aqui, a perspectiva também é clara:

A implementação da BNCC, apresenta-se como uma oportunidade ímpar para implementação de uma política de Estado que promova o aprimoramento da atuação dos professores em sala de aula com vistas a impactar positivamente o processo educativo dos estudantes brasileiros. (CONSED, 2017).

Nas últimas duas décadas, os cursos de licenciatura no Brasil têm passado por reformas. As primeiras Diretrizes Curriculares Nacionais para formação inicial de professores (DCNs) foram instituídas em 2002 com o intuito principal de desvincular as licenciaturas dos cursos de bacharelado, dar a elas projetos específicos e currículos próprios e modificar a configuração da formação até então vigente denominada de $3+$ $1^{7}$ (CNE, 2002). Estas DCNs foram influenciadas por pesquisas educacionais que fazem oposição ao modelo de racionalidade técnica, ou seja, à formação de professores como profissionais técnicos, que deveriam apenas aplicar conceitos, metodologias e teorias pedagógicas na prática (Diniz-Pereira, 2007). De acordo com Andrade et al. (2004), as DCNs de 2002 introduzem no cenário brasileiro um novo modo de compreensão sobre a formação de professores e a docência, ao entenderem a escola e a prática docente como locais de produção de conhecimento e o professor como um profissional que reflete sobre a sua prática e, nesse processo, produz saberes necessários à sua profissão.

7 Nesta configuração os cursos de formação de professores eram constituídos por três anos de bacharelado, seguido de um ano de disciplinas pedagógicas (Ayres, 2005). 
Treze anos mais tarde, em 2015, novas DCNs procuraram avançar na indicação de necessidades formativas e, além do reconhecimento da docência como espaço de produção de conhecimentos, apontaram campos de conhecimento e estudos fundamentais à formação e atuação do professor, tais como [...] "questões socioambientais, éticas, estéticas e relativa à diversidade étnico-racial, de gênero, sexual, religiosa, de faixa geracional e sociocultural como princípios de equidade” (CNE, 2015, p. 5). Embora estas novas DCNs já mencionem uma "base comum nacional" para formação de professores o documento trata de temas para valorização do magistério, como piso salarial e condições de trabalho, sem associar progressão ou bonificações por desempenho nas avaliações como pretende a BNCFP:

A efetividade dos referenciais está relacionada a sua articulação a mecanismos que assegurem o seu alcance e a condições político-institucionais que propiciem clima de confiança e colaboração entre professores e gestores. No caso da formação inicial, eles podem estar alinhados aos mecanismos de avaliação e acreditação dos cursos de formação inicial e avaliação dos estudantes ou recém-graduados. Eles também podem estar articulados a mecanismos de certificação ou registro para controlar o ingresso à carreira. Ao longo da carreira, eles podem impactar o desenvolvimento profissional e formação continuada e estar vinculados à permanência e progressão na carreira por meio de certificações, avaliações e aumentos salariais. (MEC, 2018, p. 21-22, grifos nossos).

Esta diferença importante entre as DCNs de 2015 e a BNCFP, em termos de controle via testagem e avaliações (muito mais evidentes nesta última), também está relacionada a mudanças na Política Nacional de Formação de Profissionais do Magistério da Educação Básica (PNFP). As DCNs de 2015 foram construídas a partir da PNFP instituída pelo Decreto n. 6.755 de 2009, revogado e substituído pelo Decreto n. 8.752 que, já em seu primeiro artigo, afirma que:

$\$ 3$ - O Ministério da Educação, ao coordenar a Política Nacional de Formação dos Profissionais da Educação Básica, deverá assegurar sua coerência com:

I - as Diretrizes Nacionais do Conselho Nacional de Educação - CNE;

II - com[sic] a Base Nacional Comum Curricular;

III - com [sic] os processos de avaliação da educação básica e superior; [...] (Decreto n. 8.752, 2016, grifo nosso).

A BNCFP foi elaborada a partir deste novo decreto, no qual há maior prevalência e relevância dos processos avaliativos para formação inicial e continuada de professores. Na página 29, o documento da BNCFP apresenta quadro de "visão sistêmica" da formação docente no país (Figura 3, anteriormente apresentada). Nela dois eixos (formação inicial e continuada) estão associados a diversos processos de avaliação e ao plano de carreira. Nas DCNs de 2015 a valorização do magistério constitui um eixo a parte, composto por diversos fatores como piso salarial, dedicação exclusiva, [...] "destinação de 1/3 (um terço) da carga horária de trabalho a outras atividades pedagógicas inerentes ao exercício 
do magistério" (CNE, 2015, p. 15), entre outros.

$\mathrm{O}$ anúncio existente no texto da BNCFP de possíveis mudanças nas atuais DCNs "[...] o estabelecimento desta base nacional poderá, por sua vez, orientar a atualização que for necessária das Diretrizes Curriculares Nacionais já editadas pelo CNE para a formação inicial e continuada dos Professores da Educação Básica [...]" (MEC, 2018, p. 9), se confirma claramente no objetivo de Parecer levado à consulta pública (que é abordado com mais detalhe no pós-escrito):

[...] fazer uma revisão e atualização da Resolução CNE/CP № 2/2015, levando em conta a legislação vigente, em especial às Resoluções CNE/CP N ${ }^{\circ} 02 / 2017$ e No 04/2018, definidas com fundamento, respectivamente, nos Pareceres CNE/CP no 15/2017 e $n^{\circ}$ 15/2018 que instituíram e definiram a implementação da Base Nacional Comum Curricular (BNCC) para o conjunto de etapas e de modalidades da Educação Básica. (CNE, 2019b, p. 1).

Embora mencione "revisão e atualização", para nós trata-se de completa transformação das DCNs de 2015, com a organização de uma formação centrada em competências e controle através de avaliações que irão regular o ingresso, a carreira e os salários:

[...] para formação inicial de professores, os referenciais podem estar alinhados aos mecanismos de avaliação e acreditação dos cursos de formação inicial e avaliações dos estudantes ou recém-graduados. Também podem estar articulados à mecanismos de certificação ou registro para controlar o ingresso na carreira docente. Ao longo da carreira, eles podem impactar o desenvolvimento profissional e a formação continuada, e podem estar vinculados à permanência e progressão na carreira por meio de certificações, avaliações e aumentos salariais. (CNE, 2019b, p. 11-12).

Além disso, até mesmo campos de conhecimento e estudo ${ }^{8}$ conquistados historicamente nas DCNs de 2015 foram modificados e/ou retirados. De acordo com Hypolito (2019), as DCNs de 2015 passaram por amplo processo de discussão entre os anos de 2013 e 2014 e constituem uma proposta que tenta solucionar um desafio antigo dos cursos de formação docente: compatibilizar aumento de carga horária teóricas de fundamentação com aumento de carga horária de prática para diminuir a dicotomia na formação. Com apenas quatro anos de implementação, tempo insuficiente para desenvolvimento e amadurecimento daquelas DCNs, nos parece irresponsável mudar novamente o rumo da formação de professores.

8 Formação na área de políticas públicas e gestão da educação, seus fundamentos e metodologias, direitos humanos, diversidades étnico-racial, de gênero, sexual, religiosa, de faixa geracional, Língua Brasileira de Sinais (Libras), educação especial e direitos educacionais de adolescentes e jovens em cumprimento de medidas socioeducativas. (CNE, 2015, p. 11). 


\section{5) Avaliações em Larga Escala vão Regular Tudo?}

Na introdução da BNCFP, indica-se que avaliações em larga escala (internacionais e nacionais) são importantes para gerar dados decisivos para monitorar a eficácia das políticas educacionais e analisar os fatores que incidem em seus resultados:

Diante dessas evidências, é possível afirmar que, se a sociedade do conhecimento trouxe a educação para a sua agenda estratégica, as análises dos dados de avaliação trouxeram o professor para sua agenda estratégica da educação como um dos elementos de maior importância para que a aprendizagem dos alunos aconteça. (MEC, 2018, p. 6, grifo nossos).

Em relação à realidade nacional, afirma-se que há séries históricas de análise das aprendizagens dos estudantes que mostram que persistem os problemas de baixo desempenho: "na alfabetização, os resultados das últimas avaliações indicam que quase metade dos alunos do terceiro ano do ensino fundamental ainda não estão alfabetizados" (MEC, 2018, p. 6) e que "o mau desempenho preocupa também no segundo segmento do ensino fundamental e no ensino médio que indicam a maioria dos alunos em níveis mais baixos do que proficientes" (MEC, 2018, p. 6). Diante disso, explicita-se a necessidade do desenvolvimento de uma política "estruturada", que "define", dê "referência" e estabeleça aprendizagens essenciais ao longo da escolaridade básica:

[...] como previsto na Constituição Federal/1998, na LDB/1996 e no PNE/2014, a Base Nacional Comum Curricular - BNCC/2017 - para a Educação Básica. Ela define as aprendizagens essenciais para cada etapa de ensino e em cada componente curricular. A BNCC visa à formação integral do aluno e, para isso, as competências específicas são consubstanciadas pelas dez competências gerais por ela instituídas, no sentido de garantir o pleno exercício da cidadania e do mundo do trabalho.

Na BNCC, o país estabelece uma orientação estruturada dos resultados que a nação espera das escolas e dá visibilidade à sociedade sobre o que esperar em cada ano e etapa da Educação Básica para assegurar que os direitos de aprendizagem dos alunos estão sendo atendidos. Mais importante ainda, a BNCC deverá ser, daqui em diante uma referência na formação inicial e continuada dos professores. (MEC, 2018, p. 6-7, grifos nossos).

É inegável que existem inúmeros desafios que devemos enfrentar na educação básica de nosso país. Mas é muito problemático o fato de que o mapeamento dessa situação seja feito apenas via resultados em testes padronizados. Igualmente, que as modificações nos processos de ensino-aprendizagem, tidos como necessários, sejam averiguadas, novamente, via testes. O fenômeno educativo é complexo e a formação humana que esperamos que ocorra nas escolas, nos moldes do que é estabelecido pela LDBEN, não pode ser medido apenas por avaliações pontuais de Português e Matemática, eventualmente Ciências, sem o devido acompanhamento do processo educativo in loco e sem considerar o que professores têm a dizer.

No extrato de texto acima, afirma-se, ainda, que a BNCC materializa os resultados que a nação espera que as escolas tenham a fim de que se assegurem direitos 
de aprendizagem. Contudo, um aspecto importante para a discussão aqui colocada é que a BNCC é um documento sem referências teóricas e metodológicas, que teve diferenças muito grandes entre suas três versões e que a autoria do documento sempre esteve fortemente relacionada com o trabalho do MEC, CONSED, UNDIME (União Nacional dos Dirigentes Municipais de Educação) e pelo Movimento pela Base (organizado, sobretudo, pelo grupo Todos pela Educação). Estas últimas são organizações que sofrem grande influência de grupos empresariais, conforme podemos constatar nas Figuras 4 a 7 :

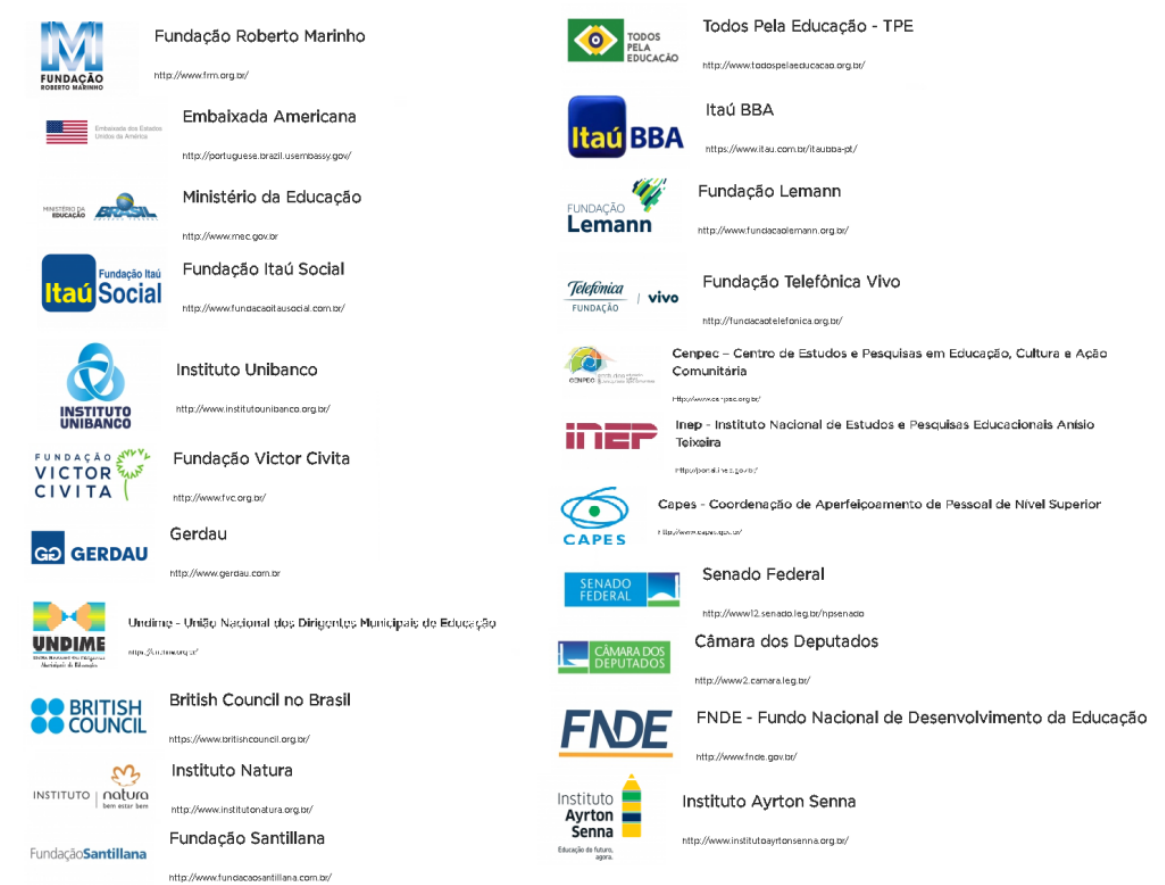

Figura 4. Parceiros do CONSED (http://www.consed.org.br/parceiros)

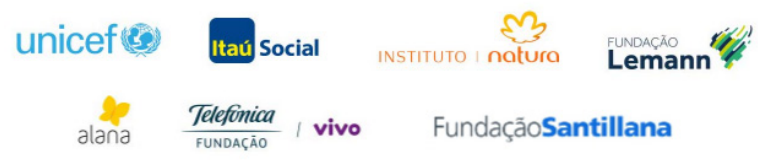

Figura 5. Parceria institucional da UNDIME (https://undime.org.br/)

$\begin{array}{llll}\text { Abave } & \text { Cenpec } & \begin{array}{l}\text { Comunidade } \\ \text { Educativa Cedac }\end{array} & \text { Consed } \\ \text { Fundação Lemann } & \begin{array}{l}\text { Fundação Maria } \\ \text { Cecilia Souto Vidigal }\end{array} & \begin{array}{l}\text { Fundação Roberto } \\ \text { Marinho }\end{array} & \begin{array}{l}\text { Instituto Ayrton } \\ \text { Senna }\end{array} \\ \text { Instituto Inspirare } & \text { Instituto Natura } & \text { Instituto Unibanco } & \text { Itaú BBA } \\ \text { Todos Pela Educação } & \text { Undime } & & \end{array}$

Figura 6. Apoio institucional do Movimento pela Base (http://movimentopelabase.org.br/ quem-somos/) 


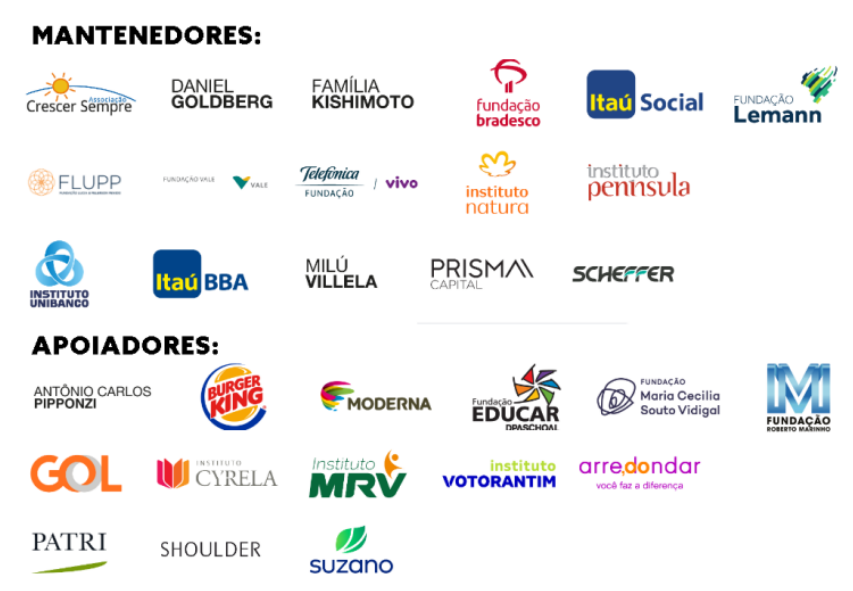

Figura 7. Mantenedores e apoiadores do Todos pela Educação (https://www.todospelaeducacao.org.br/ pag/quem-somos/)

Ou seja, a BNCC preconiza resultados de aprendizados pautados por empresas. Ademais, mesmo que sempre tenha havido algum nível de centralização curricular no Brasil, é inédita a forma como foi definido o que deve ser ensinado e aprendido em cada ano e em cada componente curricular em todo o território nacional como faz a BNCC, ainda mais quando esta foi elaborada de forma verticalizada e sem efetivo diálogo com a comunidade escolar e acadêmica. Além disso, a noção de direitos de aprendizagem presentes na terceira versão do documento foi muito reduzida quando estes foram tornados sinônimos a competências e habilidades que devem ser desenvolvidas pelos estudantes. O texto da BNCFP afirma ainda que avaliações irão regular a habilitação para docência, o ingresso na docência e a progressão na carreira: "os referenciais podem ser usados como mecanismos de ingresso na carreira docente e seleção de professores, sendo combinados a processos de certificação ou avaliação no final da graduação ou no início da carreira docente" (MEC, 2018, p.22). Neste documento, também lemos que:

Os referenciais podem orientar os sistemas educacionais a respeito do que deve ser desenvolvido no início da carreira docente, durante os períodos chamados de início, e ao longo dela, o que inclui programas de treinamento e mentoria no início, mecanismos de certificação após o probatório, sistemas de avaliação atrelados ou não à progressão na carreira e mudanças salariais e processos de formação continuada e desenvolvimento profissional. (MEC, 2018, p. 22-23, grifo nossos).

Afirma-se também que o Exame Nacional de Desempenho dos Estudantes (ENADE) poderá servir como instrumento de habilitação à docência e "como outros exames internacionais, pode servir ainda como ingresso na carreira, pois sua aprovação pode ter validade de cinco anos" (MEC, 2018, p. 35). Vemos igualmente a ênfase nos exames se prolongando pela vida profissional do docente:

A formação continuada deve ser atrelada à evolução funcional ao longo da carreira do docente. A cada etapa da carreira, o professor desenvolverá novas habilidades e competências podendo ser comprovadas por meio de avaliações, titulação e desempenho. (MEC, 2018, p. 37). 
A BNCFP menciona o exemplo da Austrália, onde há referenciais para quatro níveis da carreira docente (professores recém-graduados, professores proficientes, professores altamente experientes e professores líderes). Naquele país, estes referenciais são usados para avaliar a performance para cada nível da carreira dos professores e que, conforme a progressão nesses níveis, orientam as revisões salariais dos professores. Nesse sentido, tece-se uma proposta semelhante para o Brasil (de níveis, progressões e revisões salariais conforme avaliação de performance docente), que repetidamente vem copiando modelos estrangeiros como referência, sem a realização de uma avaliação crítica à respeito de adequações necessárias:

A matriz de competências permite que as avaliações sejam mais objetivas, pois pautar-se-á em habilidades e competências comprovadas ao longo da carreira. Dessa forma, quando a matriz de competências estiver completa, poderá haver quatro níveis de proficiência: 1) inicial (para o formado na graduação, para o ENADE e para o ingresso); 2) probatório (para o ingressado e que deverá apresentar novas competências e habilidades); 3) altamente eficiente (que estará na carreira mais avançada e deve apresentar competências e habilidades mais complexas); e 4) líder (que está no nível mais alto da carreira e tem responsabilidades e compromissos mais amplos). (MEC, 2018, p. 39).

Nesse momento, o questionamento feito por Macedo (2019) parece muito pertinente: por que usamos certas referências internacionais e não outras?

Finlândia, Shangai, Singapura e Japão partilhavam, segundo os autores, um contexto cultural de alta valorização da educação e da profissão docente. Uma das conclusões dos benchmarks estudados é a necessidade de "políticas de formação e remuneração de professores [...] que elevem o status da docência como profissão, de modo a atrair os candidatos academicamente mais fortes para instituições de treinamento e a encorajar formas colegiadas de responsabilização e pesquisa [...] Por que seria este, então, um benchmark para a experiência brasileira? Por que não tomamos as experiências dos quatro países/cidades que estão resenhados por seus resultados? [...] Do conjunto desses países/cidades com alto desempenho, a Finlândia é talvez o mais conhecido, não apenas pelos excelentes resultados no Pisa, mas por obtê-los a partir de políticas curriculares não centralizadas. (Macedo, 2019, p. 53).

Em síntese, a BNCFP contribui para o processo de implementação da BNCC, conforme o previsto na Resolução CNE/CP n. 2, de 22 de dezembro de 2017, que institui e orienta a implementação da BNCC. O objetivo almejado é alinhar e dar coerência ao sistema educacional brasileiro, promovendo a articulação entre os materiais didáticos presentes na escola, as avaliações externas, os currículos das redes e das escolas, assim como os projetos pedagógicos das unidades escolares:

Art. $5^{\circ} \mathrm{A}$ BNCC é referência nacional para os sistemas de ensino e para as instituições ou redes escolares públicas e privadas da Educação Básica, dos sistemas federal, estaduais, distrital e municipais, para construírem ou revisarem os seus currículos. 
$\$ 1^{\circ}$ A BNCC deve fundamentar a concepção, formulação, implementação, avaliação e revisão dos currículos, e consequentemente das propostas pedagógicas das instituições escolares, contribuindo, desse modo, para a articulação e coordenação de políticas e ações educacionais desenvolvidas em âmbito federal, estadual, distrital e municipal, especialmente em relação à formação de professores, à avaliação da aprendizagem, à definição de recursos didáticos e aos critérios definidores de infraestrutura adequada para o pleno desenvolvimento da oferta de educação de qualidade.

$\$ 2^{\circ} \mathrm{A}$ implementação da BNCC deve superar a fragmentação das políticas educacionais, ensejando o fortalecimento do regime de colaboração entre as três esferas de governo e balizando a qualidade da educação ofertada. (CNE, 2017, p. 5, grifo nossos).

\section{6) BNCFP: Valorização ou Testagem do Professor?}

Apesar do texto da BNCFP mencionar em diversos trechos que "[...] a qualidade do sistema educacional está firmemente ancorada em uma visão sistêmica que valoriza os professores da educação básica, visto que são eles que formam cidadãos para os níveis subsequentes de educação [...]" (MEC, 2018, p. 6, grifo nosso) é difícil crer na proposta e na pretensa valorização docente. Isto porque na BNCFP a valorização docente está concreta e diretamente relacionada ao desempenho do professor (e de seus alunos) em testes padronizados. Além disto, porque carreira e salário passam a ser atrelados ao desempenho em provas. De acordo com Tardif (2013), há três décadas, professores sentem que ganhos já obtidos - como carreira, proteção, estabilidade de emprego, aposentadoria, entre outros - estão ameaçados e sendo substituídos por uma profissionalização baseada em concorrência, prestação de contas, salário segundo mérito e instabilidade no emprego.

Sabe-se há tempos que tal lógica de valorização docente não funciona. Escolas com situações institucionais, sociais e estruturais mais adequadas potencialmente saemse melhor nos exames, independentemente do trabalho do professor. Em um trabalho realizado em escolas públicas de cidades de Minas Gerais, Calderano et al. (2010) encontrou uma correlação com significância estatística entre o resultado das escolas no Índice de Desenvolvimento da Educação Básica (IDEB) e a condição de trabalho do professor, principalmente o caráter provisório de trabalho: a rotatividade dos professores ficou diretamente relacionada a um baixo resultado no índice.

Para Hypolito (2019), associar a qualidade do trabalho docente a resultados de testes padronizados é reduzi-la a testes de múltipla escolha, é aferi-la por métricas simplistas. Concordamos com este autor quando afirma que o desempenho nos exames está relacionado a diversos fatores:

As condições de trabalho e de salário a que o magistério está submetido são muito precárias, estando as escolas públicas, elas próprias, em condições também muito precárias. Além disso, o financiamento da educação pública é bastante insuficiente, assim como a formação docente, que está submetida a regras e condições muito distantes daquelas consideradas adequadas. Com efeito, esta premissa [de que melhorar 
a qualidade docente a partir do resultado dos estudantes em testes padronizados é a forma mais eficaz de melhorar os testes educacionais] é absolutamente inadequada para aferir qualidade docente. (p. 191).

\section{7) A BNCFP Muda até a Finalidade da Educação, aquela que está na Constituição!}

Sob nosso ponto de vista, em termos de orientações e princípios, a BNCC e a BNCFP contrariam o disposto na Constituição em no mínimo dois aspectos: a finalidade da educação no Brasil e o princípio da liberdade de ensino.

Com relação à finalidade, $o$ artigo 205 é claro:

A educação, direito de todos e dever do Estado e da família, será promovida e incentivada com a colaboração da sociedade, visando ao pleno desenvolvimento da pessoa, seu preparo para o exercício da cidadania e sua qualificação para o trabalho. (Constituição, 1988, grifo nosso).

Paradoxal e inconstitucionalmente, o texto da BNCFP sustenta que

A centralidade do tradicional processo de ensino e de aprendizagem não está mais na atividade-meio do repasse de informações, mas [na] atividade-fim do zelo pela aprendizagem dos alunos, uma vez que a finalidade primordial das atividades de ensino está nos resultados de aprendizagem. (MEC, 2018, p.27, grifo nosso).

Conforme já abordamos, esses resultados de aprendizagem são identificados pelo desempenho nas avaliações em larga escala. Mas, a finalidade das atividades de ensino e da educação estabelecida pela Constituição não é formar cidadãos?

Um dos princípios constitucionais básicos da educação no Brasil, também é ferido pela BNCFP:

Art. 206. O ensino será ministrado com base nos seguintes princípios: [...] II - liberdade de aprender, ensinar, pesquisar e divulgar o pensamento, a arte e o saber; III - pluralismo de ideais e de concepções pedagógicas, e coexistência de instituições públicas e privadas de ensino; [...] (Constituição, 1988).

Como podemos crer na adoção, no desenvolvimento e na valorização da liberdade e do pluralismo estabelecidos como princípios do ensino em nossa Carta Magna quando, conforme vimos, a homogeneização e o alinhamento de conteúdos e objetivos são características marcantes da BNCFP, porque são princípios estruturantes da BNCC? Lembremos apenas de um emblemático exemplo na BNCC: o (quase) desaparecimento da palavra gênero neste documento.

\section{8) A BNCFP Parece desconhecer o Trabalho do Professor!}

\section{Para a BNCFP,}

São simples, mas não triviais, as incumbências do professor: trabalho de equipe, planejamento, ensinar cuidando com que o aluno aprenda, tratar com atenção maior os que têm dificuldade para aprender, dar aulas e outras atividades previstas na proposta 
pedagógica e em seu plano de trabalho, e ajudar na relação da escola com a família e a comunidade. (MEC, 2018, p. 27, grifos nossos).

No âmbito da OCDE diversos estudos e pesquisas demonstram uma tendência do trabalho docente à prostração, diversificação e complexificação (Tardif, 2013). De acordo com o autor, pesquisadores apontam uma intensificação do trabalho dos professores caracterizada

[...] 1) pela obrigação dos professores de fazerem mais com menos recursos, 2) por uma diminuição do tempo gasto com os alunos, 3) pela diversificação de seus papéis (professores, psicólogos, policiais, pais, motivadores, entre outros), 4) pela obrigação do trabalho coletivo e da participação na vida escolar, 5) pela gestão cada vez mais pesada de alunos do ensino público em dificuldade, 6) finalmente, por exigências crescentes das autoridades políticas e públicas face aos professores que devem se comportar como trabalhadores da indústria, ou seja, agir como uma mão de obra flexível, eficiente e barata. (Tardif, 2013, p. 563).

Por isso, questionamos e discordamos da caracterização simplista do trabalho docente apontada pela BNCFP. Por outro lado, talvez só desconhecendo e desconsiderando a complexidade da atividade docente pode-se crer que avaliações de larga escala realmente quantificam e classificam processos de ensino-aprendizagem.

\title{
9) Licenciandos nas Escolas, ou da Necessária Habilidade de diferenciar Qualidade e Quantidade!
}

\begin{abstract}
A proposta da BNCFP sustenta que
[...] O estudante da licenciatura precisa estar no ambiente de aprendizagem, em que modalidade seja, desde o primeiro semestre do curso. Seria muito pertinente ter um programa em que o licenciando estivesse semanalmente na escola sob orientação de seu orientador da Instituição formadora e sob responsabilidade de um professor experiente na escola ou em outro ambiente de aprendizagem. (MEC, 2018, p. 33, grifo nosso).
\end{abstract}

A área de pesquisa de formação de professores defende a importância da aproximação do licenciando com o campo de atuação profissional para a formação docente desde a década de 1990, através de teorizações sobre a epistemologia da prática e os saberes docentes. A crítica à racionalidade técnica e sua dicotomização entre teoria e prática gerou uma série de estudos e pesquisas que procuravam dar conta da complexidade de fenômenos e ações envolvidas na atividade docente (Monteiro, 2001).

De acordo com Nóvoa (2017) a transição da formação de professores das escolas normais para as universidades no período de 1987-1992 trouxe avanços significativos para o campo da formação, sobretudo pela ligação com a pesquisa e pela aproximação dos professores com outras profissões do conhecimento. Porém:

[...] nos últimos anos, tem vindo a crescer um sentimento de insatisfação, que resulta da existência de uma distância profunda entre nossas ambições teóricas e a realidade concreta das escolas e dos professores, como se fosse um fosso intransponível entre 
a universidade e as escolas, como se a nossa elaboração acadêmica pouco tivesse contribuído para transformar a condição socioprofissional dos professores. (p. 11081109).

Buscando superar a dicotomia constatada entre teoria e prática, desde as DCNs de 2002, houve, na legislação, aumento da carga horária destinada a aproximar mais o licenciando do campo profissional: implementação das 400 horas de prática como componente curricular e aumento da carga horária de estágio supervisionado. As DCNs de 2015 mantiveram estes componentes curriculares e procuraram qualificar a compreensão sobre eles, trazendo elementos que não estavam explícitos nas DCNs de 2002.

Porque então estamos questionando a BNCFP quando ela trata da aproximação dos licenciandos com a escola? Porque há diferenças, também neste aspecto, entre as DCNs de 2015 e as propostas da BNCFP. No contexto da nova legislação proposta, podese perceber que atividades acadêmicas como o estágio, a prática como componente curricular e a residência pedagógica são vistos como momentos para os estudantes se alinharem à BNCC. O edital do Programa Residência Pedagógica, por exemplo, afirma que um dos objetivos principais do programa é "promover a adequação dos currículos e propostas pedagógicas dos cursos de formação inicial de professores da educação básica às orientações da Base Nacional Comum Curricular (BNCC).” (CAPES, 2018, p. 1)

Desta forma, a aproximação do licenciando com o campo profissional não seria a mesma defendida pela área de pesquisa em formação de professores, uma vez que ela objetiva implementar uma política nacional de formação de professores que caminha para a desprofissionalização docente.

A aproximação do futuro professor com o campo do trabalho é importante porque há saberes da profissão docente que são desenvolvidos em contato com a atividade profissional, com a escola e com professores da educação básica. Também não negamos que, embora estejamos avançando, ainda há grande distância entre os conhecimentos aprendidos na universidade e aqueles necessários para exercício da profissão docente em escolas públicas de educação básica. Acreditamos que a tarefa de aproximar ambos locais de formação é imprescindível, embora não seja fácil. Ela requer vontade política, investimento, valorização das instituições formadoras e de seus profissionais. É difícil qualificar esta aproximação sem planejamento e sem destinar parte da carga horária do docente da educação básica para coformação de futuros professores, por exemplo. Isso significa reduzir sua carga horária em sala de aula, contratar mais professores. Há que pensar também em condições de estrutura física para desenvolver as atividades nas escolas e nas universidades. Docência não é vocação e não se faz (apenas) por amor ou por missão. A docência precisa ser considerada uma profissão que necessita condições mínimas para acontecer, em respeito aos seus profissionais e àqueles que usufruem de seus serviços. Então, nos perguntamos: há espaço e condições para todos os licenciandos na escola? Quais as condições de trabalho dos docentes para isto? Aumentar a quantidade de tempo dos licenciandos no ambiente de trabalho garante aumento na qualidade da 
formação? Estas indagações são resultantes de nossas indagações sobre a necessidade da inserção do licenciando no universo escolar e de nossa preocupação com a qualidade, formato, condições e, principalmente, objetivos com os quais esta inserção é proposta no documento.

\section{0) Pela Primeira Vez, a Formação do Professor será Baseada em Competências e Habilidades}

A BNCFP considera, erroneamente, que o currículo comprometido com o desenvolvimento de competências se constitui como um paradigma dominante na educação no Brasil. Ao contrário, há muitas críticas por parte da comunidade acadêmica e escolar do uso da "pedagogia das competências" nos currículos, uma vez que há outras formas possíveis de organização curricular e que a própria noção de "competências" é diversificada:

É verdade que o termo competência é bem conhecido de educadores em muitas e diversas acepções, nos desdobramentos da racionalidade tyleriananos anos 1970, no cognitivismo piagetiano, na tradição linguística de Chomsky e na discussão alemã no campo da formação profissional. No cenário internacional pós-1990, no entanto, ficou notabilizado pelos documentos da Unesco, especialmente o Relatório Delors. [...] Sem dúvida, já aí estava a ideia de que a educação é estratégia chave para a produtividade econômica, o bem-estar individual e social e a inclusão socioeconômica [...] O uso espraiado da noção de competência nos currículos nacionais não pode, portanto, ser deslocado do contexto em que a OCDE busca ampliar sua governança, não apenas por números e comparações, mas também por conceitos. (Macedo, 2019, p. 47).

A autora afirma, ainda, que "há razoável consenso entre os pesquisadores de que ela vem sendo exercida de forma branda (soft governance), por meio da criação de uma linguagem internacional para a comparação de resultados educacionais" (Macedo, 2019, p. 47) e que o PISA tem sido uma das principais ferramentas da OCDE para manter sua governança, que vem orientando a métrica das avaliações nacionais. Especificamente em relação à noção de competência, Macedo (2019) aponta que a OCDE publicou um documento que visava à "definição e seleção de competências-DeSeCo, que apresenta uma noção de competência muito semelhante àquela expressa na BNCC, a saber: "mobilização de conhecimentos (conceitos e procedimentos), habilidades (práticas, cognitivas e socioemocionais), atitudes e valores para resolver demandas complexas da vida cotidiana, do pleno exercício da cidadania e do mundo do trabalho." (MEC, 2017, p. 8).

O documento da BNCFP explicita três "dimensões" gerais da "competência profissional" do professor que devem ser articuladas e interagir entre si (Figura 8). 


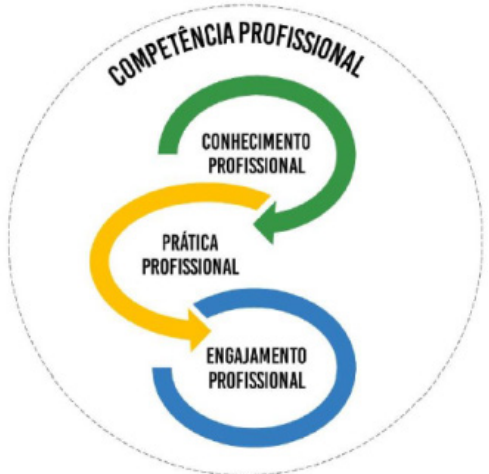

Figura 8. Dimensões da competência profissional do professor (MEC, 2018, p. 49)

Tais dimensões têm relação com as dez competências que os professores teriam que ter na atualidade, a partir do que é defendido por Perrenoud (2000), a saber (que ele tenha a competência de): 1) organizar e dirigir situações de aprendizagem, 2) administrar a progressão das aprendizagens, 3) conceber e fazer com que os dispositivos de diferenciação evoluam, 4) envolver os alunos em suas aprendizagens e em seu trabalho, 5) trabalhar em equipe, 6) participar da administração da escola, 7) informar e envolver os pais, 8) utilizar as novas tecnologias, 9) enfrentar os deveres e dilemas éticos da profissão, 10) administrar a própria formação continuada.

Ao compararmos as competências identificadas na BNCC com as apresentadas pela BNCFP percebemos que, para além de seu número ser o mesmo, a natureza dessas é muito semelhante item por item. Isto corrobora a hipótese de um alinhamento entre o que se espera que se aprenda pelos alunos na educação básica e o que se espera que os professores aprendam e ensinem. Na Figura 9 apresentamos um comparativo das competências entre os documentos.

\begin{tabular}{|c|c|}
\hline Competências da BNCC & Competências da BNCFP \\
\hline $\begin{array}{l}\text { 1. Valorizar e utilizar os conhecimentos } \\
\text { historicamente construídos sobre o mundo } \\
\text { físico, social, cultural e digital para entender e } \\
\text { explicar a realidade, continuar aprendendo e } \\
\text { colaborar para a construção de uma sociedade } \\
\text { justa, democrática e inclusiva. }\end{array}$ & $\begin{array}{l}\text { 1. Compreender e utilizar os conhecimentos } \\
\text { historicamente construídos para poder ensinar } \\
\text { a realidade com engajamento na aprendizagem } \\
\text { do aluno e na sua própria aprendizagem } \\
\text { colaborando para a construção de uma } \\
\text { sociedade justa, democrática e inclusiva. }\end{array}$ \\
\hline $\begin{array}{l}\text { 2. Exercitar a curiosidade intelectual e recorrer } \\
\text { à abordagem própria das ciências, incluindo } \\
\text { a investigação, a reflexão, a análise crítica, a } \\
\text { imaginação e a criatividade, para investigar } \\
\text { causas, elaborar e testar hipóteses, formular e } \\
\text { resolver problemas e criar soluções (inclusive } \\
\text { tecnológicas) com base nos conhecimentos das } \\
\text { diferentes áreas. }\end{array}$ & $\begin{array}{l}\text { 2. Pesquisar, investigar, refletir, realizar a análise } \\
\text { crítica, usar a criatividade e soluções tecnológicas } \\
\text { para selecionar, organizar com clareza e planejar } \\
\text { práticas pedagógicas desafiadoras, coerentes e } \\
\text { significativas. }\end{array}$ \\
\hline
\end{tabular}

Figura 9. Competências gerais presentes na BNCFP e na BNCC (continua) 


\begin{tabular}{|c|c|}
\hline Competências da BNCC & Competências da BNCFP \\
\hline $\begin{array}{l}\text { 3. Valorizar e fruir as diversas manifestações } \\
\text { artísticas e culturais, das locais às mundiais, e } \\
\text { também participar de práticas diversificadas da } \\
\text { produção artístico-cultural. }\end{array}$ & $\begin{array}{l}\text { 3. Valorizar e incentivar as diversas } \\
\text { manifestações artísticas e culturais, das locais } \\
\text { às mundiais, e a participação em práticas } \\
\text { diversificadas da promoção artístico-cultural } \\
\text { para que o aluno possa ampliar seu repertório } \\
\text { cultural. }\end{array}$ \\
\hline $\begin{array}{l}\text { 4. Utilizar diferentes linguagens - verbal } \\
\text { (oral ou visual-motora, como Libras, e escrita), } \\
\text { corporal, visual, sonora e digital -, bem } \\
\text { como conhecimentos das linguagens artística, } \\
\text { matemática e científica, para se expressar e } \\
\text { partilhar informações, experiências, ideias e } \\
\text { sentimentos em diferentes contextos e produzir } \\
\text { sentidos que levem ao entendimento mútuo. }\end{array}$ & $\begin{array}{l}\text { 4. Utilizar diferentes linguagens - verbal, } \\
\text { corporal visual, sonora e digital para } \\
\text { expressar e fazer que o aluno se expresse } \\
\text { para partilhar informações, experiências, } \\
\text { ideias e sentimentos em diferentes } \\
\text { contextos produzindo sentidos que levem ao } \\
\text { entendimento mútuo. }\end{array}$ \\
\hline $\begin{array}{l}\text { 5. Compreender, utilizar e criar tecnologias } \\
\text { digitais de informação e comunicação de } \\
\text { forma crítica, significativa, reflexiva e ética nas } \\
\text { diversas práticas sociais (incluindo as escolares) } \\
\text { para se comunicar, acessar e disseminar } \\
\text { informações, produzir conhecimentos, resolver } \\
\text { problemas e exercer protagonismo e autoria na } \\
\text { vida pessoal e coletiva. }\end{array}$ & $\begin{array}{l}\text { 5. Compreender, utilizar e criar tecnologias } \\
\text { digitais de informação e comunicação de } \\
\text { forma crítica, significativa, reflexiva e ética } \\
\text { nas diversas práticas docentes, como recurso } \\
\text { pedagógico e como ferramenta de formação, } \\
\text { para comunicar, acessar e disseminar } \\
\text { informações, produzir conhecimentos, } \\
\text { resolver problemas e potencializar as } \\
\text { aprendizagens. }\end{array}$ \\
\hline $\begin{array}{l}\text { 6. Valorizar a diversidade de saberes e vivências } \\
\text { culturais e apropriar-se de conhecimentos e } \\
\text { experiências que lhe possibilitem entender } \\
\text { as relações próprias do mundo do trabalho } \\
\text { e fazer escolhas alinhadas ao exercício da } \\
\text { cidadania e ao seu projeto de vida, com } \\
\text { liberdade, autonomia, consciência crítica e } \\
\text { responsabilidade. }\end{array}$ & $\begin{array}{l}\text { 6. Valorizar a formação permanente para o } \\
\text { exercício profissional, estar sempre atualizado } \\
\text { na sua área de atuação e nas áreas afins, } \\
\text { apropriar-se de novos conhecimentos e } \\
\text { experiências que lhe possibilitem ser um } \\
\text { profissional eficaz e fazer escolhas alinhadas } \\
\text { ao exercício da cidadania ao seu projeto de } \\
\text { vida com liberdade, autonomia, consciência } \\
\text { crítica e responsabilidade. }\end{array}$ \\
\hline $\begin{array}{l}\text { 7. Argumentar com base em fatos, dados } \\
\text { e informações confiáveis, para formular, } \\
\text { negociar e defender ideias, pontos de vista e } \\
\text { decisões comuns que respeitem e promovam os } \\
\text { direitos humanos, a consciência socioambiental } \\
\text { e o consumo responsável em âmbito local, } \\
\text { regional e global, com posicionamento ético em } \\
\text { relação ao cuidado de si mesmo, dos outros e } \\
\text { do planeta. }\end{array}$ & $\begin{array}{l}\text { 7. Buscar desenvolver argumentos com base } \\
\text { em fatos, dados e informações confiáveis } \\
\text { para formular, negociar e defender ideias, } \\
\text { pontos de vista e decisões comuns que } \\
\text { respeitem e promovam os direitos humanos, } \\
\text { a consciência socioambiental e o consumo } \\
\text { responsável em âmbito local, regional e } \\
\text { global, com posicionamento ético em relação } \\
\text { ao cuidado em si mesmo, dos outros e do } \\
\text { planeta. }\end{array}$ \\
\hline
\end{tabular}

Figura 9. Competências gerais presentes na BNCFP e na BNCC (continua) 


\begin{tabular}{|l|l|}
\hline Competências da BNCC & Competências da BNCFP \\
\hline $\begin{array}{l}\text { 8. Conhecer-se, apreciar-se e cuidar de sua } \\
\text { saúde física e emocional, compreendendo-se } \\
\text { na diversidade humana e reconhecendo suas } \\
\text { emoções e as dos outros, com autocrítica e } \\
\text { capacidade para lidar com elas. }\end{array}$ & $\begin{array}{l}\text { 8. Conhecer-se, apreciar-se e cuidar de sua } \\
\text { saúde física e emocional, compreendendo-se } \\
\text { na diversidade humana e reconhecendo suas } \\
\text { emoções e a dos outros, com autocrítica e } \\
\text { capacidade para lidar com elas, para poder } \\
\text { desenvolver autoconhecimento e o autocuidado } \\
\text { nos alunos. }\end{array}$ \\
\hline $\begin{array}{l}\text { 9. Exercitar a empatia, o diálogo, a resolução de } \\
\text { conflitos e a cooperação, fazendo-se respeitar e } \\
\text { promovendo o respeito ao outro e aos direitos } \\
\text { humanos, com acolhimento e valorização } \\
\text { da diversidade de indivíduos e de grupos } \\
\text { sociais, seus saberes, identidades, culturas e } \\
\text { potencialidades, sem preconceitos de qualquer } \\
\text { natureza. }\end{array}$ & $\begin{array}{l}\text { 9. Exercitar a empatia, o diálogo, a resolução } \\
\text { de conflitos e a cooperação, fazendo-se } \\
\text { respeitar e promovendo o respeito ao outro } \\
\text { eas direitos humanos, com acolhimento e } \\
\text { valorização da diversidade de indivíduos e } \\
\text { de grupos sociais, seus saberes, identidades, } \\
\text { culturas e potencialidades, sem preconceitos } \\
\text { de qualquer natureza para promover ambiente } \\
\text { colaborativo nos ambientes de aprendizagem. }\end{array}$ \\
\hline $\begin{array}{l}\text { 10. Agir pessoal e coletivamente com } \\
\text { autonomia, responsabilidade, flexibilidade, } \\
\text { resiliência e determinação, tomando decisões } \\
\text { com base em princípios éticos, democráticos, } \\
\text { inclusivos, sustentáveis e solidários. }\end{array}$ & $\begin{array}{l}\text { 10. Agir e incentivar, pessoal e coletivamente, } \\
\text { com autonomia, responsabilidade, } \\
\text { flexibilidade, resiliência e determinação, } \\
\text { tomando decisões com base em princípio } \\
\text { éticos, democráticos, inclusivos, sustentáveis } \\
\text { e solidários para que o ambiente de } \\
\text { aprendizagem possa refletir esses valores. }\end{array}$ \\
\hline
\end{tabular}

Figura 9. Competências gerais presentes na BNCFP e na BNCC (continuação)

Vários pesquisadores da área de Educação percebem empiricamente e avaliam que a formação inicial de professores no Brasil tem sido tradicionalmente pensada a partir das ciências e dos diversos campos disciplinares. Por isto, há necessidade de mudanças nas estruturas institucionais e nos currículos de formação inicial de professores, pois fragmentações formativas são nítidas. Ou seja, mudanças são necessárias - e concordamos com este diagnóstico - mas é inédito, para a formação de professores, definir um currículo de formação centrado em competências e habilidades, as quais estão articuladas - e limitadas - com o que é pretendido na BNCC e pelas necessidades oriundas das demandas do mundo do trabalho.

As três dimensões gerais da competência profissional são explicitadas conforme um esquema apresentado à página 50 do documento da BNCFP (Figura 10) e detalhadas nas páginas 53 a 55 . 


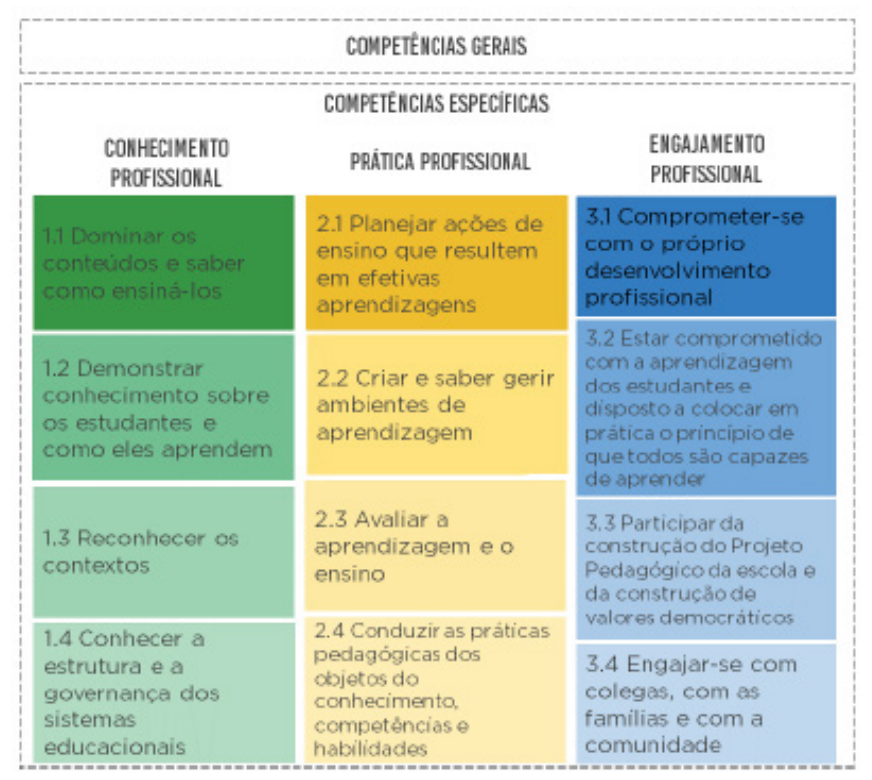

Figura 10. Competências gerais e específicas da BNCFP (MEC, 2018, p. 50)

Temos, dessa forma, uma agenda de formação, uma espécie de script fechado, que apresenta uma lógica homogeneizante e focada nos resultados, que não deixa margem para pensar a formação para a docência numa perspectiva larga e que considere a complexidade do ensinar, a diversidade dos contextos de trabalho, a pluralidade social dos discentes com os quais o professor lida e, sobretudo, para promover um desenvolvimento que valorize efetivamente esse profissional (Farias, 2019, p. 163).

Resta-nos indagar se e como é possível medir em testes a prática e o engajamento profissional.

\section{Considerações finais}

Não podemos deixar de deplorar o processo vertical, pouco transparente e nada discutido que originou esta proposta de base, conforme também aponta Farias (2019). Não desconhecemos o complexo processo de elaboração da BNCC, que teve três versões, com equipes de elaboração distintas, com objetivos diversos e que chegou ao cabo com mais dissensos do que consensos. Tampouco nos iludimos com a inacreditável consulta que resultou em 12 milhões de comentários à BNCC (Freitas, 2017) e pretensamente, por isto, dita democrática, ou com a série de audiências públicas sobre a base do Ensino Médio que nem chegaram a se completar, pelo grau de mobilização e contrariedade das comunidades escolar e acadêmica ao conteúdo da proposta. Mas assinalamos que a proposta da BNCFP não circulou, não foi conhecida e não foi discutida para além de seu restrito círculo de elaboração antes da data de seu lançamento.

Por fim, é importante destacar que a construção de currículos envolve processos de seleção ligados à construção de respostas para perguntas como: O que se deve saber? Que conhecimento é importante ou válido ou essencial para ser considerado como parte 
do currículo? Que pessoa espera-se formar para a vida em sociedade?

A própria palavra currículo, etimologicamente (do latim curriculum) significa caminho, o qual não se reduz a uma série de conteúdos que devem ser apreendidos pelos sujeitos para a construção de certas competências que possibilitem que ele atue de forma mais ou menos eficiente na sociedade. Currículo tem relação com a formação das pessoas, que, central e vitalmente, está envolvida naquilo que somos, naquilo que nos tornamos, tendo relação com a nossa identidade, com a nossa subjetividade (Silva, 2005). Por isso, questões curriculares estão situadas em um campo epistemológico e social, estando, portanto, em um território contestado e tais divergências podem ser percebidas quando discutimos a BNCC, BNCFP ou qualquer outro documento curricular. Em outras palavras, não é necessário, nem possível que o currículo seja o mesmo em todas as escolas, pois ele precisa fazer sentido e ser construído contextualmente, atender demandas e necessidades que não são homogêneas (Lopes, 2019).

Nesse sentido, precisamos pensar, conjuntamente - inclusive para a organização de resistências - qual projeto e caminho educacional defendemos e queremos, para a educação básica e para a formação de professores.

Não precisamos usar referências internacionais que parecem privilegiar a pauta financeira em detrimento da educativa na educação. Podemos e precisamos organizar um outro e nosso projeto de formação, que atenda às demandas e à realidade brasileira.

O processo de implementação de políticas curriculares é tão político quanto o processo de sua elaboração. Infelizmente, muitas vezes os elaboradores de políticas os veem como apartados e esquecem-se que os professores também as produzem. Esperamos ter contribuído para a reflexão de cada uma e de cada um sobre o conteúdo da BNCFP, seus pressupostos e propostas. Também almejamos ter contribuído para que o conhecimento do tema nos estimule ainda mais a cerrar fileiras contra esta proposta que avilta a inteligência docente, desvaloriza o professor e quer subalternizá-lo em um sistema de controle baseado em simplificações pueris (como por exemplo, a de que se o aluno não aprende um suposto conhecimento e uma competência julgada por outrem como importante, a culpa cabe inteiramente ao professor).

Ora, sabemos todos da importância do professor e por isso estamos aqui. Por isto trabalhamos e pesquisamos no campo da Educação em Ciências. Mas ignorar que a atividade do professor, para além de sua formação, depende de suas condições de trabalho, salário, carreira, condições de vida é no mínimo uma incompetência muito grande. Da mesma maneira, entendemos que chega às raias da maldade e das más intenções, isolar a aprendizagem dos alunos de fatores como condições sociais e econômicas, de vida digna e de esperança de futuro. 


\section{Pós-escrito}

De maio a novembro de 2019, ocorreram modificações e decisões sobre a BNCFP, que culminaram com a aprovação, pelo CNE, de um documento de 20 páginas intitulado "Projeto de Resolução CNE/CP No XXX/2019. Define Diretrizes Curriculares Nacionais para a Formação Inicial de Professores para a Educação Básica, e institui a Base Nacional Comum para a Formação Inicial de Professores da Educação Básica (BNC-Formação)"10. Trazemos neste pós-escrito um resumo dos principais acontecimentos envolvidos nesta aprovação. Esta seção tem caráter informativo e complementar à análise do documento da BNCFP (MEC, 2018). A análise dos documentos ${ }^{11}$ que vieram a público em novembro por si só demandaria vários textos e está por ser feita.

Desde a redemocratização, após o período de ditadura civil-militar brasileira, as proposições feitas pelo CNE costumavam ser de conhecimento público, sendo socializadas pela imprensa e pelas entidades nele representadas, assim como era recorrente a realização de audiências públicas, feitas em muitos estados e regiões de nosso país, para socialização e deliberação acerca das políticas públicas que eram instituídas pelo Conselho. Isso mudou.

Neste trabalho, analisamos especificamente o documento intitulado "Proposta para Base Nacional Comum da Formação de Professores da Educação Básica” (MEC, 2018) divulgado no dia 13/12/2018 e encaminhado ao CNE no dia $14 / 12 / 2018$, no término do Governo Temer. Desse momento até o final de setembro de 2019, poucas informações foram disponibilizadas acerca dos debates sobre a BNCFP no CNE, havendo apenas a emissão de uma resolução (CNE, 2019a) prorrogando o prazo para implementação das DCN de 2015.

No dia 26/9/2019, um documento intitulado "3a VERSÃO DO PARECER (Atualizada em 18/09/19) ASSUNTO: Diretrizes Curriculares Nacionais e Base Nacional Comum para a Formação Inicial e Continuada de Professores da Educação Básica" (CNE, 2019b) foi apresentado pelo CNE para uma consulta pública que duraria um mês. As versões $1^{\text {a }}$ e $2^{\text {a }}$ deste documento não foram divulgadas, o que indica que o debate público e democrático foi insuficiente, pois foi restrito a apenas um documento gestado previamente pelos membros do $\mathrm{CNE}^{12}$. É pertinente destacar que a consulta pública foi

\footnotetext{
9 Texto escrito entre novembro e dezembro de 2019, após a apresentação da mesa redonda no ENPEC.

10 Este documento ainda não foi publicado no Diário Oficial. Ele foi divulgado pelos presentes na sessão do CNE, e circulou informalmente na comunidade acadêmica.

11 Além do acima citado, existe (1) o documento intitulado "3a versão do parecer (Atualizada em 18/09/19) Assunto: Diretrizes Curriculares Nacionais e Base Nacional Comum para a Formação Inicial e Continuada de Professores da Educação Básica." CNE (2019b)e (2) documento intitulado "Estrutura do Parecer", no formato de três slides, que foi divulgado pelos presentes na reunião do Colégio de Pró-reitores da Associação Nacional dos Dirigentes das Instituições Federais de Ensino Superior (COGRAD-ANDIFES)e que tem circulado na comunidade acadêmica.

12 O CNE teve sua composição alterada em 28/06/2017, em meio à grande ebulição política, sendo, desde então, reconhecidamente formado por inúmeros reformadores empresariais que representam e apresentam interesses privatistas na/para a educação.
} 
feita a partir do recebimento de contribuições somente por meio eletrônico (email) e em formato texto. Paradoxalmente a decisão do CNE ocorreu no dia 7/11/2019, antes da audiência pública agendada para dia 8/11/2019. Esta ocorreu com participação máxima prevista para 200 pessoas e sem divulgação prévia das contribuições e posicionamentos feitos durante a consulta pública.

No dia 7/11/2019, CNE apresentou o documento intitulado "3a VERSÃO DO PARECER (Atualizada em 18/09/19) ASSUNTO: Diretrizes Curriculares Nacionais e Base Nacional Comum para a Formação Inicial e Continuada de Professores da Educação Básica" (CNE, 2019b). Antes disso, na mesma semana, em uma reunião do Colégio de Pró-reitores da Associação Nacional dos Dirigentes das Instituições Federais de Ensino Superior (COGRAD-ANDIFES) houve a divulgação, através de documento no formato de três slides, da estrutura deste Parecer. Segundo estes slides, os pontos de destaque do parecer são; (1) com a nova Resolução propõe-se uma agenda de aprendizagem para os professores, alinhada à BNCC; (2) a organização da formação é baseada em competências profissionais docentes, sob três dimensões (conhecimento, prática e engajamento profissional), em que indicam-se dez competências docentes gerais, competências específicas e habilidades; (3) a organização da carga horária dos cursos de formação tem parte comum (grupo I), de 800 horas, parte de aprofundamento (grupo II), de 1600 horas e parte prática (grupo III), com $800 \mathrm{~h}$, sendo $400 \mathrm{~h}$ para o estágio; e (4) formação/complementação pedagógica e segunda licenciatura em 1.000h, podendo vir a ser $600 \mathrm{~h}$, se houve aproveitamento de $400 \mathrm{~h}$.

Nos slides, prevê-se, também, que (5) haverão diretrizes específicas para a formação continuada, assim como para a docência em Modalidades de Ensino (tais como Educação Especial, Educação do Campo, Educação Indígena, Educação Quilombola,); (6) que as Instituições de Ensino Superior que já implementaram plenamente o previsto na Resolução de 2015 do CNE não devem sofrer quebra de continuidade quanto às suas atividades, devendo fazer, quando necessário, as adequações ao novo Parecer nos próximos dois anos, enquanto que as Instituições que não implementaram plenamente a referida Resolução, terão o mesmo prazo de dois anos para efetivar a devida adequação curricular; (7) que o Instituto Nacional de Estudos e Pesquisas Educacionais Anísio Teixeira (INEP) irá implementar um sistema de avaliação de qualidade do egresso dos cursos; e (8) que a formação inicial de profissionais do magistério dará preferência ao ensino presencial.

De modo geral, em todos os espaços ocorreram manifestações vigorosas e generalizadas de contrariedade à proposta de Reformulação da Resolução CNE/CP n. 2/2015, sendo que algumas notas foram redigidas, entre elas, aquela emitida em $09 / 10 / 2019$, assinada por trinta entidades acadêmicas e sindicais da área da educação ${ }^{13}$

13 "Contra a descaracterização da Formação de Professores - Nota das entidades nacionais em defesa da Res. 02 /2015”. Recuperado de http://www.anped.org.br/news/contra-descaracterizacao-da-formacao-de-professoresnota-das-entidades-nacionais-em-defesa-da 
e outra assinada pelo COGRAD-ANDIFES ${ }^{14}$. Até o momento, a única manifestação oficial do CNE sobre o processo foi a do relator da comissão bicameral do CNE, Mozart Ramos, atual diretor de articulação e inovação do Instituto Ayrton Senna e membro do CNE, que, no dia 21/11/2019, publicou, no jornal Folha de São Paulo, uma coluna sobre a aprovação da nova Resolução sobre as DCN de formação de professores ${ }^{15}$.

Sobre os mais recentes acontecimentos, a versão final da nova Resolução foi homologada pelo MEC em dezembro de 2019 e incorporou, em partes, aquilo que estava previsto na BNCFP (MEC, 2018). Mas, é importante compreendermos que a nova Resolução, antes de qualquer coisa, chancela o movimento de alinhamento e estreitamento curricular da formação de professores à Reforma do Ensino Médio (Lei n. 13.415, 2017), à BNCC da Educação Infantil e Ensino Fundamental (2017) e à BNCC do Ensino Médio (2018), assim como dá outro rumo para aquilo que vinha sendo entendido e construído como Diretrizes para a formação de professores em nosso país.

Estamos vivendo um período repleto de golpes e reformas indiretas e, no campo educacional, essas profundas alterações desencadeiam inúmeros retrocessos, principalmente, no que tange à educação pública como bem público. Isso pode ser evidenciado a partir da recente expansão da atuação de Organizações Sociais na gestão da educação pública ${ }^{16}$, do estabelecimento do Programa Nacional de Escolas Cívico Militares ${ }^{17}$, da Reforma do Ensino Médio (que propõe a ampliação de carga horária da etapa de ensino, sem ampliação da estrutura pública para esse atendimento) (Lei n. 13.415, 2017), da ampliação do cerceamento sobre o trabalho docente a partir das mudanças nos materiais didáticos a serem distribuídos nas escolas ${ }^{18}$ e das avaliações a serem realizadas pelos estudantes ${ }^{19}$ e professores ${ }^{20}$.

Por fim, as mudanças que têm ocorrido no campo educacional vêm operando no sentido de mascarar e desconsiderar influências de fatores extraescolares. Isto gera uma nefasta forma de organização das escolas e das instituições formadoras de professores, do trabalho didático-pedagógico, da estrutura da carreira docente e da construção das aprendizagens por parte dos estudantes. Estas, passam a incorporar o imperativo de ideias como individualização, competição, responsabilização e empreendedorismo com vistas

14 COGRAD - Colégio de Pró-Reitores de Graduação "MANIFESTAÇÃO - DIRETRIZES CURRICULARES NACIONAIS PARA A FORMAÇÃO DE PROFESSORES”. Recuperado de http://apub.org.br/wp-content/ uploads/2019/11/Manifestac\%CC\%A7a\%CC\%83o-COGRAD-DCNs-formac\%CC\%A7a\%CC\%83o-deprofessores.pdf

15 Novas diretrizes para a formação de professores: Qualidade do docente é o fator principal na educação.

Recuperado de https:/www1.folha.uol.com.br/opiniao/2019/11/novas-diretrizes-para-a-formacao-deprofessores.shtml

16 A partir da publicação do Parecer CNE/CEB n 10/2016(CNE, 2016) tem ocorrido, em vários estados e municípios do país, a expansão da contratação de Organizações Sociais pelo poder público.

17 Escola Cívico-militar. Recuperado de http://escolacivicomilitar.mec.gov.br/

18 Alterações no Programa Nacional do Livro Didático-PNLD (Decreto n. 9.099, 2017).

19 Mudanças no SAEB (Portaria n. 271, 2019).

20 Estabelecimento do Exame Nacional de Avaliação do Magistério da Educação Básica (ENAMEB), já aprovado em comissão própria e aguardando aprovação no Congresso (https://www.camara.leg.br/noticias/460679comissao-aprova-exame-nacional-para-avaliar-professores-da-educacao-basica/). 
a formar o trabalhador flexível do futuro mediante o desenvolvimento de competências e habilidades de caráter praticista e tecnicista. Isso apaga, sobretudo, as propostas que vinham sendo tecidas até então, asseguradas, inclusive, por via constitucional, que focavam no desenvolvimento da pessoa, da solidariedade, do respeito à diversidade e do fomento à pluralidade de ideias, concepções e metodologias.

Nestes tempos sombrios, cabe-nos ultrapassar o temor mediante conhecimento, reflexão e debate coletivo para construir ações de contestação e resistência.

\section{Agradecimentos}

Agradecemos à CAPES pela concessão de bolsas às duas primeiras autoras, aos integrantes do Grupo Casulo: pesquisa e educação em Ciências e em Biologia, especialmente aos integrantes do grupo de orientação coletiva "Bússola”, pelas discussões e questionamentos que enriqueceram o texto. Agradecemos também aos pareceristas da RBPEC que, com sua leitura crítica e comentários contribuíram para a elaboração da versão final do texto.

\section{Referências}

Andrade, E. P., Ferreira, M. S., Vilela, M. L., Ayres, A. C. M., \& Selles, S. E. (2004). A dimensão da prática na formação inicial docente em Ciências Biológicas e em História: modelos formativos em disputa. Ensino em Re-vista, 12(1), 7-21. Recuperado de http:// www.seer.ufu.br/index.php/emrevista/article/view/7912

Ayres, A. C. M. (2005). As tensões entre a licenciatura e o bacharelado: a formação dos professores de biologia como território contestado. In M. Marandino, S. Selles, M. Ferreira, \& A. C. Amorim (orgs.), Ensino de Biologia: conhecimentos e valores em disputa (pp. 182-197). Niterói: Editora Eduff.

Constituição da República Federativa do Brasil de 1988 (1988). Recuperado de http:// www.planalto.gov.br/ccivil_03/constituicao/constituicao.htm

Calderano, M. A., Pereira, M. C., \& Marques, G. F. C. (Org.). (2010). Campos e vertentes: formação, trabalho docente e avaliação sistêmica. Juiz de Fora: Editora UFJF.

CAPES (Coordenação de Aperfeiçoamento de Pessoal de Ensino Superior) (2018). Edital CAPES n. 06/2018 Programa de Residência Pedagógica. Chamada Pública para apresentação de propostas no âmbito do Programa de Residência Pedagógica. Recuperado de https://capes.gov.br/images/stories/download/editais/01032018-Edital6-2018-Residencia-pedagogica.pdf

Cássio, F. L. (2018). Base Nacional Comum Curricular: ponto de saturação e retrocesso na educação. Retratos da Escola, 12(23), p. 239-253. http://dx.doi.org/10.22420/rde. v12i23.887 
CNE (Conselho Nacional de Educação) (2002). Parecer CNE/CP 09 de 08 de maio de 2001, publicado em 18 de janeiro de 2002. Proposta de Diretrizes Curriculares Nacionais para a formação de Professores da educação básica, em nível superior, curso de licenciatura, de graduação plena. Recuperado de http://portal.mec.gov.br/cne/ arquivos/pdf/009.pdf

CNE (Conselho Nacional de Educação) (2015). Resolução CNE/CP 02 de $1^{\circ}$ de julho de 2015. Define as Diretrizes Curriculares Nacionais para a formação inicial em nível superior (cursos de licenciatura, cursos de formação pedagógica para graduados e cursos de segunda licenciatura) e para a formação continuada. Recuperado de http:// portal.mec.gov.br/docman/agosto-2017-pdf/70431-res-cne-cp-002-03072015-pdf/file

CNE (Conselho Nacional de Educação) (2016). Parecer CNE/CEB No: 10/2016. Consulta sobre a legalidade de Organizações Sociais administrarem escolas públicas em Goiás. Recuperado de http://portal.mec.gov.br/index.php?option=com docman\&view=download\&alias $=49141$-pceb010-16-pdf\&category_slug $=$ outubro2016-pdf\&Itemid=30192)

CNE (Conselho Nacional de Educação) (2017). Resolução n. 2, de 22 de dezembro de 2017. Institui e orienta a implantação da Base Nacional Comum Curricular, a ser respeitada obrigatoriamente ao longo das etapas e respectivas modalidades no âmbito da Educação Básica. Recuperada de http://basenacionalcomum.mec.gov.br/images/ historico/RESOLUCAOCNE_CP222DEDEZEMBRODE2017.pdf

CNE (Conselho Nacional de Educação) (2019a). Resolução n. 1, de 2 de julho de 2019. Altera o Art. 22 da Resolução CNE/CP no 2, de $1^{\circ}$ de julho de 2015, que define as Diretrizes Curriculares Nacionais para a formação inicial em nível superior (cursos de licenciatura, cursos de formação pedagógica para graduados e cursos de segunda licenciatura) e para a formação continuada. Recuperado de http://portal.mec.gov. $\mathrm{br} /$ index.php?option $=$ com_docman \&view $=$ download\&alias $=116731-\mathrm{rcp} 001-$ 19\&category_slug=julho-2019-pdf\&Itemid $=30192$

CNE (Conselho Nacional de Educação) (2019b). 3a versão do parecer (Atualizada em 18/09/19) Assunto: Diretrizes Curriculares Nacionais e Base Nacional Comum para a Formação Inicial e Continuada de Professores da Educação Básica. Recuperado de http://portal.mec.gov.br/index.php?option=com_docman\&view=download\&a lias $=124721$-texto-referencia-formacao-de-professores\&category_slug=setembro2019\&Itemid $=30192$

CONSED (Conselho Nacional de Secretários de Educação) (2017). Formação de professores: sobre o grupo. Recuperado de http://www.consed.org.br/consed/formacaocontinuada-de-professores/sobre-o-grupo-de-trabalho

Decreto n. 8.752, de 9 de maio de 2016 (2016). Dispõe sobre a Política Nacional de Formação dos Profissionais da Educação Básica. Recuperado de http://www.planalto. gov.br/ccivil_03/_Ato2015-2018/2016/Decreto/D8752.htm 
Decreto n. 9.099, de 18 de julho de 2017 (2017). Dispõe sobre o Programa Nacional do Livro e do Material Didático. Recuperado de http://www.planalto.gov.br/ccivil_03/_ ato2015-2018/2017/decreto/D9099.htm

Di Giovanni, G. (2009). Estruturas Elementares das Políticas Públicas. Cadernos de Pesquisa, 82, 2-23. Recuperado de https://www.nepp.unicamp.br/biblioteca/periodicos/ issue/view/9/CadPesqNepp82

Diniz-Pereira, J. E. (2007). Formação de professores: pesquisas, representações e poder. 2 ed. Belo Horizonte: Autêntica.

Farias, I. M. S. de (2019). O discurso curricular da proposta para BNC da formação de professores da educação básica. Retratos da Escola, 13(25), 155-168. http://dx.doi. org/10.22420/rde.v13i25.961

Freitas, L. C. (2012). Os reformadores empresariais da educação: da desmoralização do magistério à destruição do sistema público de educação. Educação e Sociedade, 33(119), 379-404. http://dx.doi.org/10.1590/S0101-73302012000200004

Freitas, L. C. (2014). Os empresários e a política educacional: como o proclamado direito à educação de qualidade é negado na prática pelos reformadores empresariais. Germinal: Marxismo e Educação em Debate, 6(1), 48-59. http://dx.doi.org/10.9771/ gmed.v6i1.12594

Freitas, L. C. (2016). Três teses sobre as reformas empresariais da educação: perdendo a ingenuidade. Caderno Cedes, 36(99), 137-153. http://dx.doi.org/10.1590/CC010132622016160502

Freitas, L. C. (2017). BNCC: o mito dos 12 milhões de participantes. Recuperado de https:// avaliacaoeducacional.com/2017/12/03/bncc-o-mito-dos-12-milhoes-de-participantes/

Hypolito, A. M. (2019). BNCC, agenda global e formação docente. Revista Retratos da Escola, 13(25), p. 187-201. http://dx.doi.org/10.22420/rde.v13i25.995

Lei n. 9.394, de 20 de dezembro de 1996 (1996). Estabelece as diretrizes e bases da educação nacional. Recuperado de http://www.planalto.gov.br/ccivil_03/leis/19394.htm

Lei n. 13.005, de 25 de junho de 2014. Aprova o Plano Nacional de Educação - PNE e dá outras providências.

Lei n. 13.415, 2017 (2017). Lei n. 13.415, de 16 de fevereiro de 2017. Altera as Leis n. 9.394, de 20 de dezembro de 1996, que estabelece as diretrizes e bases da educação nacional, e 11.494, de 20 de junho 2007, que regulamenta o Fundo de Manutenção e Desenvolvimento da Educação Básica e de Valorização dos Profissionais da Educação, a Consolidação das Leis do Trabalho - CLT, aprovada pelo Decreto-Lei n. 5.452, de $1^{\circ}$ de maio de 1943, e o Decreto-Lei n. 236, de 28 de fevereiro de 1967; revoga a Lei n. 11.161, de 5 de agosto de 2005; e institui a Política de Fomento à Implementação de Escolas de Ensino Médio em Tempo Integral. Recuperado de http://www.planalto.gov. br/ccivil_03/_Ato2015-2018/2017/Lei/L13415.htm 
Lopes, A. C. (2019). Itinerários formativos na BNCC do Ensino Médio: identificações docentes e projetos de vida juvenis. Retratos da Escola, 13(25), 59-75. http://dx.doi. org/10.22420/rde.v13i25.963

Macedo, E. F. de (2019). Fazendo a Base virar realidade: competências e o germe da comparação. Retratos da Escola, 13(25), 39-58. http://dx.doi.org/10.22420/rde. v13i25.967

Mainardes, J. (2006). Abordagem do ciclo de políticas: uma contribuição para a análise de políticas educacionais. Educação e Sociedade, 27(94), 47-69. http://dx.doi.org/10.1590/ S0101-73302006000100003

MEC (Ministério da Educação) (2016). Base Nacional Comum Curricular. Recuperada de http://basenacionalcomum.mec.gov.br/images/relatorios-analiticos/bncc-2versao. revista.pdf

MEC (Ministério da Educação) (2017). Base Nacional Comum Curricular. Recuperada de http://basenacionalcomum.mec.gov.br/images/BNCC_EI_EF_110518_versaofinal_ site.pdf

MEC (Ministério da Educação) (2018). Proposta para Base Nacional Comum da Formação de Professores da Educação Básica. Recuperado de http://portal.mec.gov.br/ index.php?option=com_docman\&view=download\&alias=105091-bnc-formacao-deprofessores-v0\&category_slug=dezembro-2018-pdf\&Itemid=30192

MEC (Ministério da Educação) (2018a). Base Nacional para formação do professor vai revisar cursos para conhecimento e valorização. Recuperado de http://portal.mec.gov.br/ component/content/article?id=71951

Monteiro, A. M. F. C. (2001). Professores: entre saberes e práticas. Educação \& Sociedade, 74, 121-142. http://dx.doi.org/10.1590/S0101-73302001000100008

Nóvoa, A. (2017). Firmar a posição como professor, afirmar a profissão docente. Cadernos de Pesquisa, 47(166), 1106-1133. http://dx.doi.org/10.1590/198053144843

Portaria n. 271, de 22 de março de 2019 (2019). Estabelece as diretrizes de realização do Sistema de Avaliação da Educação Básica (SAEB) no ano de 2019.

Perrenoud, P. (2000). Dez Novas Competências para Ensinar. Porto Alegre: Artmed Editora.

Santos, A. F. dos (2004). Teoria do Capital Intelectual e Teoria do Capital Humano: Estado, Capital e Trabalho na Política Educacional em dois momentos do processo de acumulação. In Anais da 27a Reunião Anual da ANPEd. Caxambu, MG. Recuperado de http://27reuniao.anped.org.br/gt09/t095.pdf

Silva, M. R. da (2019). Impertinências entre trabalho, formação docente e o referencial de competências. Retratos da Escola, 13(25), 123-135. http://dx.doi.org/10.22420/rde. v13i25.965 
Silva, T. T. (2005). Documentos de Identidade: uma introdução às teorias do currículo. Belo Horizonte: Autêntica.

Tardif, M. (2013). A profissionalização do ensino passado trinta anos: dois passos para a frente, três para trás. Educação \& Sociedade, 34(123), 551-571. http://dx.doi. org/10.1590/S0101-7330201300020001

\section{Larissa Zancan Rodrigues}

${ }^{\circ}$ https://orcid.org/0000-0003-4326-616X Universidade Federal de Santa Catarina

Programa de Pós-Graduação em Educação Científica e Tecnológica Florianópolis, Santa Catarina, Brasil larissazancan@yahoo.com.br

\section{Beatriz Pereira}

https://orcid.org/0000-0001-6659-3812 Universidade Federal de Santa Catarina Programa de Pós-Graduação em Educação Científica e Tecnológica Florianópolis, Santa Catarina, Brasil beatrizsofka@gmail.com

\section{Adriana Mohr}

${ }^{0}$ https://orcid.org/0000-0001-6741-2112 Universidade Federal de Santa Catarina

Centro de Ciências da Educação Departamento de Metodologia de Ensino Florianópolis, Santa Catarina, Brasil adriana.mohr.ufsc@gmail.com

Submetido em 16 de dezembro de 2019 Aceito em 19 de janeiro de 2020 Publicado em 24 de janeiro de 2020 